\title{
The Cambrian (Sunwaptan, Furongian) agnostoid arthropod Lotagnostus Whitehouse, 1936, in Laurentian and Avalonian North America: systematics and biostratigraphic significance
}

\author{
StePHEN R. WeStROP, JONATHAN M. AdRAIN \& ED LANDING
}

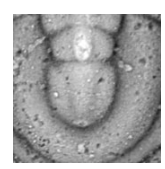

\begin{abstract}
Restudy of type and other material shows that the Cambrian (Sunwaptan, Furongian) agnostoid arthropod Lotagnostus americanus (Billings, 1860), far from being distributed globally, can be identified with confidence only at its type locality of Quebec. As such, it is ill-suited as an index for international correlation. Lotagnostus obscurus Palmer, 1955, from Nevada is not a synonym of L. americanus and is most similar to other effaced species from Australia. Sclerites from Avalonian Canada are represented by perhaps as many as two species, one of which is L. germanus (Matthew, 1901), and the other is similar to the type species, L. trisectus (Salter, 1864). However, loss of information due to compaction makes L. trisectus difficult to interpret in its type region of Avalonian Britain, and possible occurrences in other areas are therefore questionable at best. At the current state of knowledge, this species name should not be applied outside of Avalonian Britain. Aside from L. obscurus, which may possibly appear in slightly older strata, all Laurentian occurrences are confined to Upper Sunwaptan successions. Most are in the Illaenurus and Prosaukia pyrene zones, although review of material assigned to L. hedini (Troedsson, 1937) in western Newfoundland suggests that this species may occur, albeit questionably, only in the basal Skullrockian Phylacterus saylesi Fauna; indeterminate species occur in the Keithia schucherti Fauna in the latter region. Occurrences in Avalonian Canada are all from the upper Peltura Zone, and are likely somewhat younger (Saukiella junia Subzone and correlatives) than those in Laurentian successions. $\bullet$ Key words: Cambrian, agnostoid arthropod, Lotagnostus, systematics, biostratigraphy.
\end{abstract}

WeStrop, S.R., AdRAin, J.M. \& LANDing, E. 2011. The Cambrian (Sunwaptan, Furongian) agnostoid arthropod Lotagnostus Whitehouse, 1936, in Laurentian and Avalonian North America: systematics and biostratigraphic significance. Bulletin of Geosciences 86(3), 569-594 (11 figures). Czech Geological Survey, Prague. ISSN 1214-1119. Manuscript received January 6, 2011; accepted in revised form July 19, 2011; published online August 30, 2011; issued September 30, 2011.

Stephen R. Westrop, Oklahoma Museum of Natural History and School of Geology and Geophysics, University of Oklahoma, Norman, Oklahoma 73072, USA; swestrop@ou.edu・Jonathan M. Adrain, Department of Geoscience, University of Iowa, 121 Trowbridge Hall, Iowa City, Iowa 52242, USA; jonathan-adrain@ uiowa.edu • Ed Landing, New York State Museum, Albany, New York 12230,USA; elanding@mail.nysed.gov

Agnostoid arthropods have played a singular role in development of a global nomenclature of series and stages for the Middle and Upper Cambrian (Babcock \& Peng 2007). Some species, such as Glyptagnostus reticulatus (Angelin, 1851), appear to be genuinely widespread geographically (e.g., Westergård 1947, Palmer 1962, Peng \& Robison 2000), although often only in outer shelf and basinal facies (e.g., Robison 1976). However, as discussed below, evidence for broad distributions of many other species is equivocal at best. The use of agnostoids in global correlation has also been encouraged by a widespread belief that species are highly variable (e.g., Pratt 1992, Peng \& Robison 2000), although in the absence of quantitative tests, the evidence for this variability is largely anecdotal.
Indeed, many globally distributed "species" are a composite of numerous small samples, each typically inadequate for an analysis of variation, with differences between collections from various stratigraphic levels or geographic regions interpreted as intraspecific in nature. The recent proposal of Lotagnostus americanus (Billings, 1860) as a globally distributed, highly variable "index species" for the base of Cambrian Stage 10 by Peng \& Babcock (2005, Babcock \& Peng 2007) is emblematical of this approach to agnostoid systematics. Their conclusions have been accepted widely (e.g., Terfelt et al. 2008, Lazarenko et al. 2008), although Rushton (2009) has recently questioned synonymy of L. americanus and L. trisectus (Salter, 1864). 
Peng \& Babcock's revision of L. americanus was based largely on a review of the literature, with almost all of the images (2005, fig. 2) apparently reproduced from previous work. The limitations of this approach are underscored by considering the cephalon of L. americanus from Quebec that was illustrated by Peng \& Babcock (2005, fig. 2.3) with a photograph recycled from earlier work by Rasetti (1944, pl. 36, fig. 1). Our new images of this specimen, discussed below, show that Rasetti's photograph is crudely cropped posteriorly and that harsh lighting exaggerates the expression of the scrobiculation and the glabellar furrows and lobes. Consequently, his photograph is misleading in its apparent similarity to strongly furrowed cephala from other continents (e.g., Pegel 2000, fig. 15.6; Rushton 2009, fig. 2E, F).

Here we review species of Lotagnostus from Avalonian and Laurentian North America through restudy of type specimens, some of which have not been figured previously, and new collections. We also illustrate comparative material of effaced Lotagnostus from Australia. We conclude that Lotagnostus americanus is restricted to the type locality at Lévis, Quebec. Rather than a synonym of L. americanus, as suggested by Ludvigsen \& Westrop (in Ludvigsen et al. 1989), L. obscurus Palmer (1955) is more appropriately treated as a valid species; effaced Lotagnostus from northern Canada, identified by Westrop (1995) as L. americanus, cannot be assigned with certainty to any existing species.

In the Avalon Terrane of Nova Scotia, new samples of Lotagnostus and archival specimens from the Matthew collection at the New Brunswick Museum show that uncompacted cephala have faint lateral glabellar furrows on the posteroglabella, so that glabellar lobes (aside from the basal lobes) are poorly expressed. Differences in pygidia raise the possibility that two species are present, one of which is represented by the types of $L$. germanus (Matthew, 1901). We cannot be sure if similar glabellar lobe and furrow morphology characterizes neotype and topotype L. trisectus from Avalonian Britain (Rushton 2009) because these features are distorted by flattening of sclerites in shale. It is, however, likely that strongly furrowed cephala from other regions, such as Sweden (e.g., Rushton 2009, fig. 2E, F), are distinct from species from Nova Scotia, and the relationship of all of them to L. trisectus is uncertain. The name $L$. trisectus can only be applied with confidence to material from Avalonian Britain.

\section{Biostratigraphy}

At least four distinct species are present in Laurentian North America, Lotagnostus americanus (Billings), L. hedini (Troedsson, 1937), L. obscurus Palmer, and L. cf. L. trisectus sensu Rasetti, 1959; L. cf. L. trisectus sensu Rasetti, 1945 may represent a fifth. In Avalonian Canada, there may be at least two species, L. germanus (Matthew) and L. cf. L. trisectus from middle Chesley Drive Group ["MacNeil Formation" (abandoned, Landing 1996) of Hutchinson 1952)] of Nova Scotia, described here. Stratigraphic distribution is discussed in detail below (Systematic Paleontology) under each species, and is summarized in Fig. 1. Lotagnostus in Laurentia occurs largely in an interval in the Upper Sunwaptan that corresponds to the Illaenurus Zone. As suggested by Palmer (1955) and by a collection of silicified sclerites from the Cherry Creek Range documented here, the genus may appear in somewhat older strata in Nevada, perhaps correlative with the upper part of the Ellipsocephaloides Zone in Alberta (Westrop 1986). In Avalonian Canada, Lotagnostus occurs in the Peltura scarabaeoides Zone, which places it in the upper part of the range of the L. trisectus (Salter), as compiled by Rushton (2009).

A set of at least three species, L. hedini, L. asiaticus Troedsson, 1937, and L. punctatus Lu, 1964, are present in the various Chinese terranes. The close association of the latter with Hedinaspis regalis Trodesson (1937) in a well-documented section in Hunan (Wa'ergang section; Peng 1992, fig. 3) suggests that its first appearance could be older than occurrences of Lotagnostus in Laurentia. From the record of $H$. regalis in Nevada (Taylor 1976), these species could easily correlate into a level in the Lower Sunwaptan (Jiangshanian). Lotagnostus asiaticus and $L$. punctatus were considered to be conspecific with L. americanus by Peng \& Babcock (2005), but are removed from synonymy in this paper.

If $L$. cf. L. trisectus from Nova Scotia should prove to record the uncompacted morphology of L. trisectus from Avalonian Britain, then L. "trisectus" as reported from Sweden (e.g., Westergård 1922, Rushton 2009) represents an undescribed species in the Peltura Zones; similar but minimally documented material from Siberia that has been identified as L. trisectus (e.g., Pegel 2000) is of uncertain status, as are poorly known occurrences of " $L$. trisectus-like" sclerites from the Argentine Cordillera (Shergold 1995) and Tasmania (Bao \& Jago 2000).

Our interpretation of L. americanus leaves little prospect for a definition of the base of Stage 10 on a single species of Lotagnostus. Miller et al. (2006) have already suggested a level that is relatively high in the Furongian (base of the Skullrockian Stage of Laurentia), at the FAD of Cordylodus andresi, as an alternative. In a companion paper (Landing et al., this volume), we propose a datum at a lower level in the Upper Sunwaptan, the FAD of Eoconodontus notchpeakensis, to define the global Lawsonian Stage (Fig. 1).

\section{Systematic palaeontology}

Illustrated material is housed at the following repositories: CPC, Geoscience Australia; GSC, Geological Survey of 


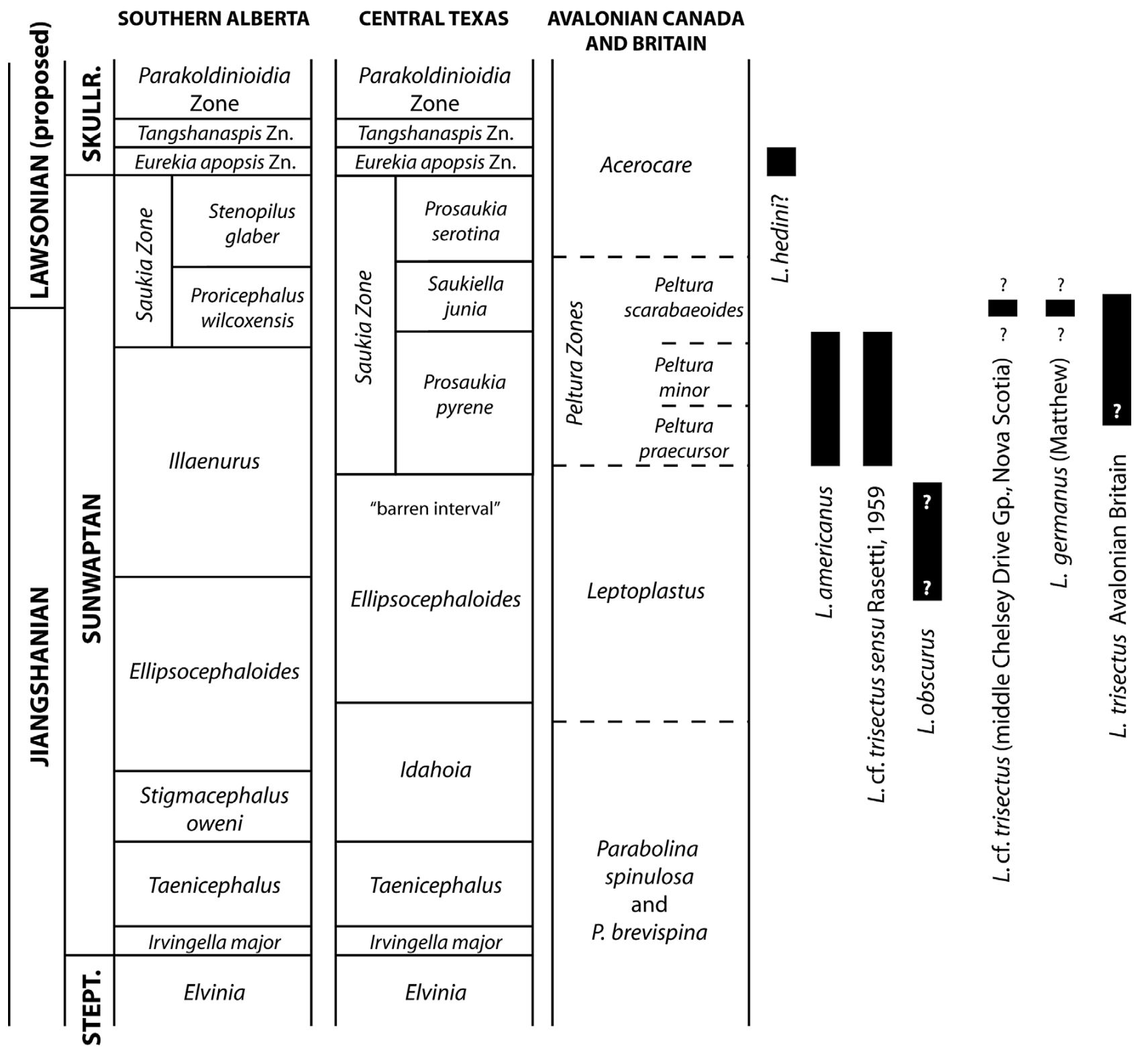

Figure 1. Correlation chart showing the distribution of Lotagnostus spp. in North America. The column for Alberta is from Westrop (1986), Texas from Longacre (1970), and Avalonia is modified from Geyer \& Shergold (2000). Zonal nomeclature for the Skullrockian of Laurentia follows Landing et al. (2011). The range for L. obscurus includes L. cf. L. obscurus from the Cherry Creek Range, Nevada (documented in this paper).

Canada, Ottawa; USNM, National Museum of Natural History, Washington, D.C.; NBMG, New Brunswick Museum; SUI, University of Iowa Paleontological Repository. In order to maximize depth of field, all digital images (except those of Fig. 7, which are conventional photographs) were rendered from stacks of images focused at 200 micron intervals using Helicon Focus 4.0 for the Macintosh (http://www.heliconsoft.com). Proportions expressed in percentages in descriptions and diagnoses are means, with numbers in parentheses indicating the range of values. All measurements were made on digital images to the nearest tenth of a millimeter using the Measure Tool of Adobe Photoshop ${ }^{\mathrm{TM}}$.
Family Agnostidae M'Coy, 1849

\section{Genus Lotagnostus Whitehouse, 1936}

Type species. - Agnostus trisectus Salter, 1864 from the White-leaved Oak Shale of Malvern, England (by original designation; see Rushton 2009).

Diagnosis. - Variably effaced, with glabella outlined fully only on ventral surface of exoskeleton in some species; segmentation of glabella and pygidial axis may also be expressed only ventrally. Long anterior lobe occupies 
one-third or more of glabellar length. In all but a few effaced species, pygidium with tripartate division ("trisection") of posteroaxis, with gently inflated intranotular axis, often outlined by notular furrows. M1 pygidial lobe tripartate, with large outer lobes outlined fully by furrow that extends from F1 to articulating furrow, even in effaced species (expressed on ventral surface of exoskeleton).

Discussion. - Shergold \& Laurie (in Whittington 1997; see also Shergold et al. 1990) recently made a comprehensive review of the agnostoid arthropods that serves as a starting point for work on this group. However, their diagnoses are largely descriptive in nature and monophyly of many genera and suprageneric taxa is questionable. Recasting the classification of agnostoids in modern phylogenetic terms will be a monumental task that is well beyond the scope of this work. We present an interim diagnosis for Lotagnostus above but recognize that a phylogenetic analysis that includes a variety of other genera will be needed for a full evaluation. Although some authors have allied Lotagnostus with Glyptagnostus (e.g., Lu \& Lin 1989, p. 214), we agree with Shergold \& Laurie (in Whittington et al. 1997, Shergold et al. 1990) that it is more likely to be related to genera currently included in family Agnostidae M'Coy, such as Agnostus Brogniart, 1822, and Homagnostus Howell, 1935. In framing a diagnosis, we have used other genera of Agnostidae (Shergold \& Laurie in Whittington et al. 1997) in assessing potential apomorphies of Lotagnostus.

Shergold et al. (1990, Shergold \& Laurie in Whittington et al. 1997) divided Lotagnostus into three subgenera based on grade of effacement: L. (Lotagnostus) includes strongly furrowed, non-effaced species, L. (Eolotagnostus) Zhou, in Zhou et al. 1982, for species that possess a weak preglabellar median furrow or lack one entirely, and L. (Distagnostus) Shergold, 1972, for species that are strongly effaced on the dorsal surface of the exoskeleton, but with details of the glabella and the pygidial axis generally expressed on the ventral surface and thus evident on internal molds (see discussion of L. cf. L. obscurus Palmer, below).

Lotagnostus (Distagnostus) intergrades with L. (Lotagnostus) via "partially effaced" species such as L. americanus, and it is likely that recognition of the L. (Distagnostus) will create paraphyly in the L. (Lotagnostus). Pending formal phylogenetic analysis, we therefore consider Distagnostus to be a junior synonym of Lotagnostus. We are less sure about the status of Eolotagnostus. Shergold \& Laurie (in Whittington et al. 1997, fig. 218.2a, 2b) present good images of the holotype cephalon and pygidium, which are characterized by a long, narrow glabella and axis, respectively. On the cephalon, a very short preglabellar median furrow is barely perceptible near the glabella, and the pygidial posteroaxis appears to lack any trace of trisection. On the other hand, Peng (1992) includes species much closer to L. trisectus (e.g., L. asiaticus Troedsson, 1937) in Eolotagnostus. We think it likely that Eolotagnostus is also a paraphyletic grade, and provisionally suppress it as a junior synonym of Lotagnostus.

More recently, Nielsen (1997) proposed Semagnostus as a subgenus of Lotagnostus, with Pseudoperonopsis zuninoi Harrington \& Leanza (1957, fig. 21.6a-c) as the type species. He regarded Semagnostus as most similar to Distagnostus but differing in the lower degree of effacement. While it is true that the glabella and pygidia axis are more clearly defined in Semagnostus, Nielsen also recognized that the "intra-axial furrows" are obsolete. Without information on the segmentation of the pygidial axis and, to a lesser extent, the glabella both in the type species and in other species attributed to Semagnostus (e.g., Lu \& Lin 1984, pl. 5, figs 1-10), it is difficult to critically evaluate the affinities of this genus. Until more data become available, Semagnostus is best treated a taxon whose relationships are uncertain.

\section{Lotagnostus cf. L. trisectus Salter, 1864}

Figures 2, 3

cf. 1864 Agnostus trisectus Salter; Salter, p. 10, pl. 1, fig. 11. cf. 1906 Agnostus trisectus Salter, 1864. - Lake, p. 10, pl. 1, figs 15,16 .

non 1945 Lotagnostus cf. L. trisectus (Salter, 1864). - Rasetti, p. 463 , pl. 60 , fig. 1 .

1952 Lotagnostus trisectus (Salter, 1864). - Hutchinson, p. 70, pl. 1, figs 6-8 [only; pl. 1, figs $9-12=$ Lotag nostus sp. indet.].

non 1959 Lotagnostus cf. L. trisectus (Salter, 1864). - Rasetti, p. 381 , pl. 51, figs 8, 9 .

cf. 1981 Lotagnostus trisectus (Salter, 1864). - Allen et al., pl. 17, figs 1,2 .

cf. 2005 Lotagnostus americanus (Billings, 1860). - Peng \& Babcock, fig. 2.5 [only].

cf. 2009 Lotagnostus trisectus (Salter, 1864). - Rushton, p. 275, figs 1A-I, P, 2A-D, G, K, L [only].

Occurrence. - Middle Chesley Drive Group, MacNeil Brook ("MacNeil Formation" of Hutchinson, 1952), Nova

Figure 2. Lotagnostus cf. L. trisectus (Salter, 1864) from the middle Chesley Drive Group ("MacNeil Formation"), MacNeil Brook (Hutchinson, 1952), Nova Scotia, collection MaNe-E-1.0. All $\times 20$ except A-C $(\times 15)$. $\bullet$ A-C - pygidium, dorsal, lateral and posterior views, NBMG 15457. -D-G - pygidium, dorsal, anterior, posterior and lateral views, NBMG 15458; H - pygidium, dorsal view, NBMG 15459 . $\bullet$ I, J - pygidium, posterior and dorsal views, NBMG 15460 . $\bullet \mathrm{K}$ - pygidium, dorsal view, NBMG 15461 . $\mathrm{L}-\mathrm{N}$ - pygidium, posterior, dorsal and lateral views, NBMG 15462. 


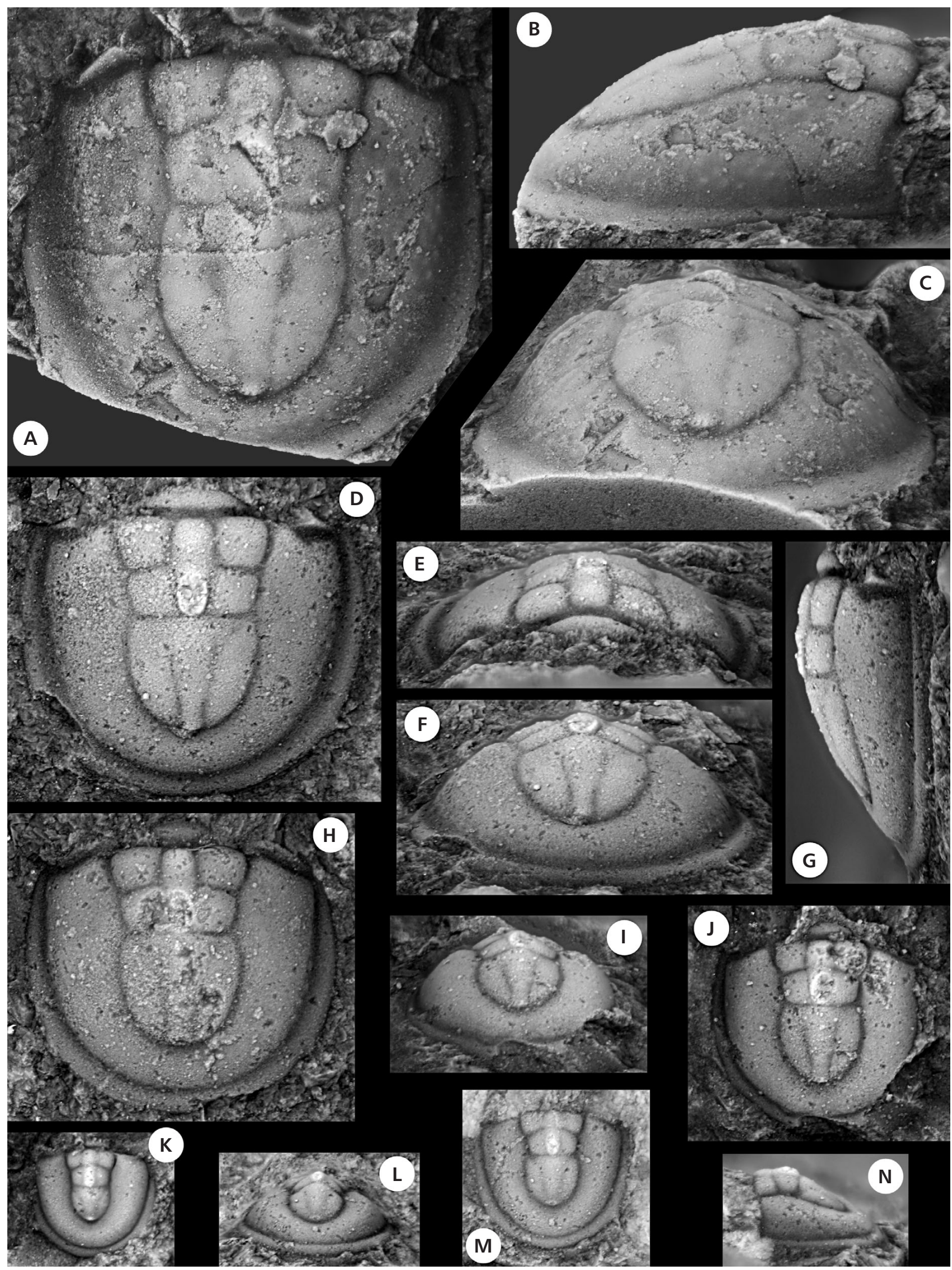


Scotia, from our collection MaNe-E-1.0 [a calcareous nodule from a low cut bank $500 \mathrm{~m}$ upstream from the MacKeigan Road bridge across MacNeil Creek - which approximately corresponds to Hutchinson's (1952) locality 18600]. It occurs with Peltura cf. P. scarabaeoides westergaardi Henningsmoen, 1957, which suggests a correlation into the middle Peltura scarabaeoides Zone, at a level roughly equivalent to the upper limit of the range of Lotagnostus trisectus in Wales (Allen et al. 1981, Rushton 2009).

Description. - Species known only from internal moulds. Cephalon semielliptical in outline, width equal to 91 percent (88-94) of length, and strongly arched in anterior and lateral views. Axial furrows narrow but well-defined grooves. Excluding basal lobes, glabella roughly parallelsided, width equal to 47 percent (47-48) of glabellar length; occupies about 70 percent of cephalic length and 35 percent of cephalic width; maximum elevation at axial node, then lateral profile slopes steeply forward, so that most of axis raised only slightly above genal field. Basal lobes roughly triangular in outline, stand well below level of adjacent median body of posteroglabella, and extend forward to point just behind level of axial node. They mark widest point of glabella, with width (tr.) immediately in front of basal lobes equal to about 60 percent of maximum width. Basal furrows well defined and diverge forward in gentle curve, so that basal lobes not "notched" into posteroglabella. Transglabellar furrow (F3) shallow and curved gently backward. Median body of posteroglabella unfurrowed except for faint F2 that proceeds inward and then curves forward without joining medially. M3 lobe indistinct, without independent convexity dorsally, but marked by slight outward bulge of posteroglabella. Anteroglabella long, length equal to about 37 percent of glabellar length, and with bluntly pointed anterior termination. Preglabellar median furrow well expressed, shallow groove extending fully from glabella to border furrow. Border furrow is shallow groove; borders gently convex, raised slightly above level of border furrows. Internal mold smooth to faintly scrobiculate.

Pygidium semi-elliptical in outline, length equal to 86 percent (82-88) of maximum width, and strongly convex; acrolobe unconstricted. Axial furrows clearly expressed but shallow. Axis occupies increasing proportion of pygidial length during holaspid ontogeny, equal to less than 70 percent of pygidia length in smallest specimens (Fig. $2 \mathrm{~K}-\mathrm{N}$ ) but exceeds 75 percent in more mature individuals (Figs 2A, D, H, 3A). Relative width of axis also size-related, with width at F2 equal to 30 percent or less of pygidial width in small holaspids (Fig. $2 \mathrm{~K}, \mathrm{M}$ ), but averaging 37 percent (34-38) later in ontogeny (Figs 2A, D, H, 3A). Axis convex, standing well above genal field, gently constricted at M2 and well-rounded posteriorly. Articu- lating furrow firmly impressed, nearly transverse and without axial recess; articulating half-ring transversely sub-elliptical in outline. Anteroaxis (excluding articulating half-ring) occupies a little less than half of axis length (46 percent; 45-48) in all but smallest specimen available (Fig. 2K; 54 percent). F1 curved gently forward from axial furrow but then turns abruptly forward adaxially to join articulating furrow. F2 transverse and connected across axis. Tripartite M1 and M2 each include two subquadrate lateral lobes. Medially, single inflated band stands above level of lateral lobes and extends uninterrupted from articulating furrow to F2; elevated into conspicuous axial node at M2. Posteroaxis trisected by very shallow notular furrows that diverge anteriorly, so that gently inflated intranotular axis is vase-shaped in outline. Conspicuous node at posterior terminus of intranotular axis. Border widens (tr.) backward opposite M1, then maintains uniform width. In smaller individuals, border furrows is shallow but "deliquiate" (Shergold 1975); border defined largely as change in slope in more mature individuals. Minute posterolateral spine present behind level of axis in smaller specimens (Fig. 2M) but apparently lost later in ontogeny (see lower right side of specimen figured in Fig. 3A-C). Surface of mold non-scrobiculate, but one large specimen with ill-defined, low tubercles on genal field (Fig. 2B).

Discussion. - Well preserved Lotagnostus cephala in collections from Nova Scotia are characterized by faint F2 furrows and ill-defined M3 lobes (e.g., Figs 3D-G, 4J-L). The M3 lobes are outlined more clearly in lightly compacted sclerites (Fig. 4G-I), which resemble the condition in cephala illustrated by Hutchinson (1952, pl. 1, figs 6, 7; note that outlines of these specimens are retouched and rather harsh lighting from the upper left likely exaggerates expression of lobes and furrows). With further compaction (Fig. 4A-C), however, F2 and M3 may be obliterated along with the preglabellar median furrow, so that taphonomic factors are a primary source of apparent morphological variation. Also, more compacted cephala have proportionately broader and more rounded outlines (Figs 4A-C, G-I) than less flattened specimens (Figs 3D-G, 4J-L); however, all taphonomic variants are non-scrobiculate to weakly scrobiculate. There is variation between collections in pygidial architecture that is not a function of compaction. Pygidia from the type lot of "L. trisectus mut. Germanus" Matthew, 1903 (Fig. 4D-F) and other material collected by Matthew (Fig. 4M-O) have trisection of the posteroaxis that is barely perceptible at best. In addition, the pygidial margins and flanks of the acrolobe converge backward, so that the pygidial outline is relatively narrow. We modify Matthew's name for this material to Lotagnostus germanus (see below). Compared to L. germanus, pygidia from collection MaNe-E-1.0 are relatively wider with a more rounded outline and unconstricted acrolobes (compare 


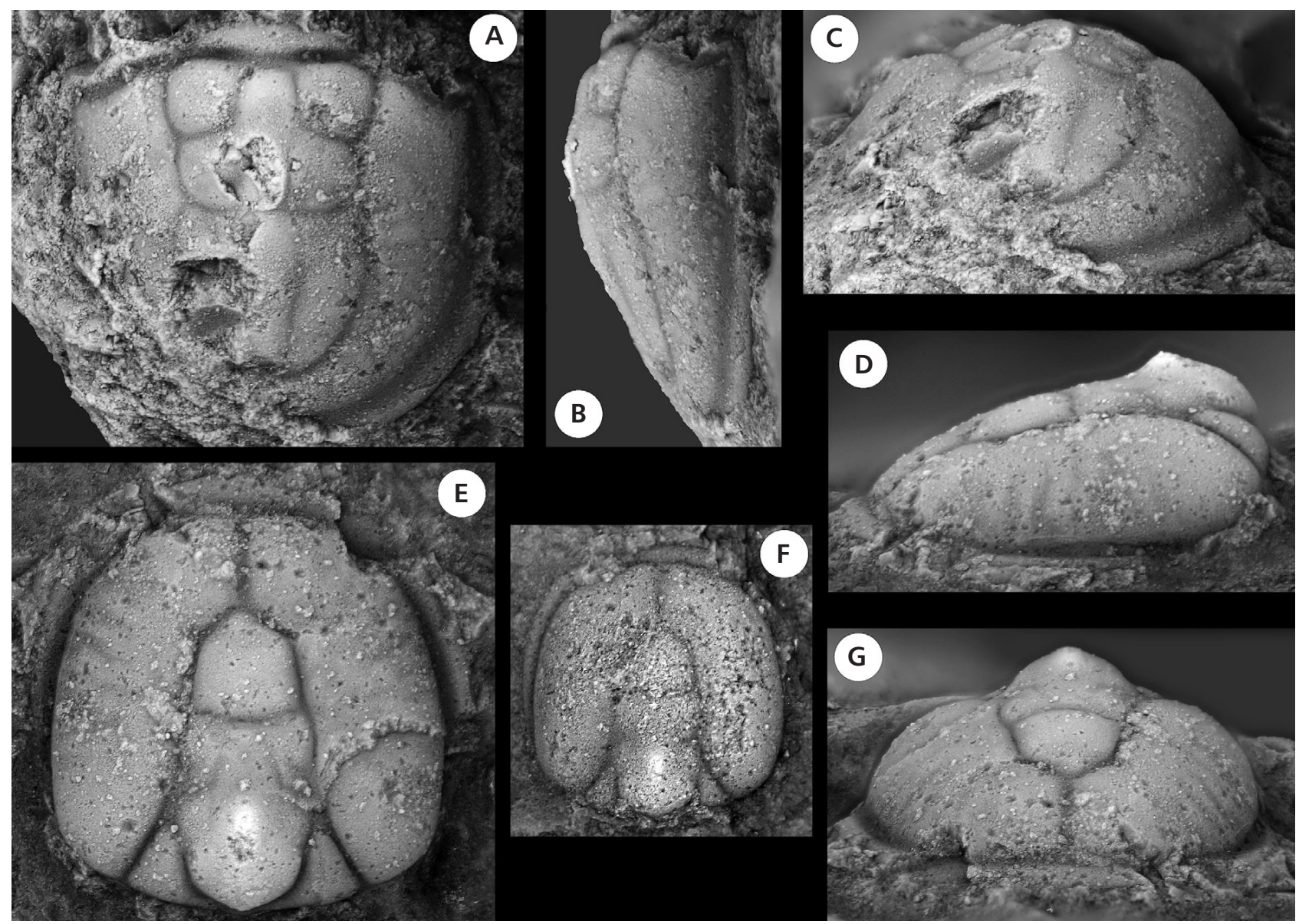

Figure 3. Lotagnostus cf. L. trisectus (Salter, 1864) from the middle Chesley Drive Group ("MacNeil Formation"), MacNeil Brook (Hutchinson, 1952), Nova Scotia, collection MaNe-E-1.0. A-C - pygidium, dorsal, lateral and posterior views, NBMG 15463, × 15. $D$ D, E, G - cephalon, lateral, dorsal and anterior views, NBMG 15464, × 18. $\bullet$ F - cephalon, dorsal view, NBMG 15465, × 18 .

similarly-sized pygidia in Figs 2D-G and 4M-O); the trisection of the posteroaxis in the latter is well-defined over a broad size range (e.g., Figs 2, 3A-C). The significance of these differences is beyond confident evaluation in the available samples; however, we are reluctant to assign material from MaNe-E-1.0 to L. germanus, and use open nomenclature instead.

Topotypes of $L$. trisectus s.s. from the type area in Malvern (Rushton 2009, fig. 1A-I, P) are flattened in shale, so that comparisons with our three-dimensionally preserved specimens from Nova Scotia are difficult. Other material from North Wales that has been assigned to the species is even less well preserved, and includes tectonically distorted and smeared specimens (Rushton 2009, fig. 2A, B, K). However, a cephalon from the Cwmhesgen Formation (Allen et al. 1981, pl. 17, fig. 1) is very similar to the neotype of L. trisectus (Rushton 2009, fig. 1a), and a pygidium from the same unit (Allen et al. 1981, pl. 17, fig. 2), although somewhat sheared, is comparable to topotypes from the White-leaved Oak Shale (e.g., Rushton 2009, fig. 1G). Consequently, we follow Rushton (2009) in interpreting the British Avalonian material as a single species.

In all specimens of L. trisectus from Avalonian Britain, taphonomic and tectonic distortion hinders evaluation of morphology. Indeed, one could argue that the name is best restricted to the neotype and topotypes. On the neotype cephalon, M3 is circumscribed completely by a finely etched groove, and the preglabellar median furrow is expressed in a similar fashion (Rushton 2009, fig. 1A). In other specimens, M3, F2 and the median preglabellar furrow have been muted (e.g., Rushton 2009, fig. 1P) or obliterated (e.g., Rushton 2009, fig. 1B) by compaction. This strong taphonomic overprint precludes any comparison with cephala from Nova Scotia. Topotype pygidia (Rushton 2009, fig. 1E-I, P) have rounded outlines, unconstricted acrolobes and well-developed trisection of the posteroaxis, although the latter is almost certainly exaggerated by compaction. In these respects, they resemble pygidia of $L$. cf. $L$. trisectus from collection MaNe-E-1.0 (Figs 2, 3A-C). The plastotype of the pygidium illustrated by Salter (1864; see Rushton 2009, fig. 1F) and one specimen 
from North Wales (Rushton 2009, fig. 2G) display F1 furrows that are connected across the axes. However, as in pygidia of both $L$. cf. L. trisectus and L. germanus from Nova Scotia, F1 furrows on the topotypes (Rushton 2009, fig. 1D, E, G-I) are deflected anteriorly along the inflated medial portions of M3 and do not join. We cannot be sure if this variation in F1 reflects the true morphology or whether it is taphonomic in nature; if the former, there could be more than one species of Lotagnostus present in the White-leaved Oak Shale. Thus, similarities in pygidia suggest that L. trisectus is related to $L$. cf. trisectus from Nova Scotia, and they might eventually prove to be conspecific. Unfortunately, uncertainties about cephalic morphology in the flattened neotype and topotypes of the former prevent a more definitive assessment.

In his revision of the species, Rushton (2009) followed the traditional practice (e.g., Linnarsson 1880, Westergård 1922, Ahlberg \& Ahlgren 1996) of assigning material from Scandinavia to L. trisectus. Despite the long history of study, there are few published illustrations, and some specimens have been recycled endlessly in figures (e.g., Westergård 1922, pl. 1, figs 11, 12; Shergold et al. 1990, fig. 9.7b; Shergold \& Laurie in Whittington et al. 1997, fig. 218.1a, b; Peng \& Babcock 2005, fig. 2.6, 2.7; Rushton 2009, fig. 2E, H). With such limited information, critical evaluation is difficult at best.

Much of the published information on the morphology of Scandinavian Lotagnostus comes from a well-preserved cephalon and pygidium from Andrarum in southern Sweden that were first illustrated by Westergård (1922, pl. 1, figs 11,12$)$. The most recent images of these sclerites by Rushton (2009, fig. 2E, F, H-J) indicate that the glabella has firmly impressed, slot-like F2 furrows and, consequently, well-defined M3. This contrasts with the subdued expression of F2 and M3 in L. cf. L. trisectus from Nova Scotia. F1 is also well incised on Westergård's cephalon, so that M2 is also clearly expressed, and the anterior tips of the basal lobes are recessed behind M2. In comparison, F1 is obsolete on L. cf. L. trisectus, and M2 is barely identifiable (Fig. 3D-G). Westergård's cephalon does, however, share the angulate anterior termination of the glabella with L. cf. L. trisectus; Rushton (2009, p. 276) considered this to be one of the character states that separated L. trisectus from L. americanus (Billings 1860). The pygidium figured by Westergård has a proportionately longer posteroaxis than those of $L$. cf. L. trisectus, and the longitudinal trisection is far better defined (see Rushton 2009, fig. 2H-J for new images). Thus, there are clear differences between L. trisectus from Sweden, as interpreted by Westergård and others, and our material from Nova Scotia. This also has implications for the identification of L. trisectus outside of Avalonian Britain. Cephala of L. cf. L. trisectus and L. "trisectus" from Sweden are differentiated from each other by the expression of their glabellar lobes and furrows.
As noted above, compaction and/or tectonic deformation has distorted or even obliterated these features in cephala from Malvern and North Wales. Thus, the long-standing practice of assigning sclerites from regions beyond England and Wales to L. trisectus is dubious at best, and we recommend that it be discontinued until uncompacted and undeformed specimens are available from the type area for comparison. We can say that the cephalon from Siberia identified as L. trisectus by Pegel (2000, fig. 15.6; later transferred to L. americanus by Lazarenko et al. 2008, pl. 23, fig. 1) is comparable to Westergård's in the morphology of the glabellar furrows and lobes, and both are strongly scrobiculate; the associated pygidium (Pegel 2000, fig. 15.10) differs from Westergård's (Rushton 2009, fig. $2 \mathrm{H}-\mathrm{J})$ in the comparatively short posteroaxis. However, like Westergård's material, these sclerites are not demonstrably conspecific with neotype and topotype L. trisectus.

Other strongly furrowed cephala are distinct from $L$. cf. L. trisectus and are more like those from Sweden and Siberia. These include two incomplete cephala illustrated by Rasetti (1959, pl. 51, figs 8, 9) from the "Grove Formation" (= Frederick Formation; Reinhart 1974), who collected them from loose blocks in a stone wall in Frederick, Maryland (his locality ccb/2). Rasetti identified these specimens as L. cf. L. trisectus, and they display the well-defined M2 and M3 lobes and slot-like F2 furrows that characterize "L. trisectus" from Baltica. They differ from the latter in having well incised preglabellar median furrows and well rounded, rather than angular, anterior ends of the glabellae. Ludvigsen \& Westrop (in Ludvigsen et al. 1989, p. 9) correlated the trilobite assemblage of locality $\mathrm{CCb} / 2$ with their Onchonotus richardsoni Fauna or perhaps the younger Keithia subclavata Fauna. This age assignment places Lotagnostus cf. L. trisectus sensu Rasetti in the Illaenurus Zone of the type Sunwaptan Stage of Alberta (Westrop 1986). Elsewhere in Laurentia, Rasetti (1945, pl. 60, fig. 1) compared an incomplete pygidium from boulder 15 from the Lévis Formation, Quebec, to L. trisectus. This clearly differs from coeval pygidia that he identified as L. americanus (Fig. 6A, B, D) in the very well developed trisection of the posteroaxis that includes firmly impressed notular furrows, and also appears to have deeper border furrows. As far as can be determined from Rasetti's image, L. cf. L. trisectus from Nova Scotia possesses a longer axis and relatively weak trisection of the posteroaxis.

Lotagnostus verrucosus (Rusconi, 1951), from the Argentinian Precordillera in Mendoza (see Shergold et al. 1995, pl. 1, fig. 12) has been transferred to L. trisectus by several authors (Shergold et al. 1990, 1995; Tortello \& Bordonaro 1997), and was included in L. americanus (Billings) by Peng \& Babcock (2005). The only known specimen, a strongly scrobiculate cephalon with well-defined F2 and M3, invites comparison with "L. trisectus" from 
Sweden, Siberia and Maryland. However, without an associated pygidium, this species is of uncertain status.

Bao \& Jago (2000) recently reported L. trisectus from a late Cambrian siltstone succession in southwestern Tasmania but, as with other records outside of East Avalonia, we consider it to be of uncertain status. The sclerites are rather poorly preserved as siltstone moulds and, as only dorsal views are presented, it is unclear as to how much compaction they have suffered. The only complete cephalon figured (Bao \& Jago 2000, pl. 1, fig. 13; misnumbered on plate as fig. 7) resembles $L$. cf. $L$. trisectus in possessing ill-defined F2 and M3. However, in contrast to L. cf. L. trisectus, all pygidia [Bao \& Jago 2000, pl. 1, figs 12, 14 and 15 (misnumbered on plate as fig. 18)] have conspicuous trisection of the posteroaxis, with the intranotular axis defined by firmly impressed notular furrows.

Several species of Lotagnostus have been named for Chinese material (e.g., Troedsson 1937; Lu 1954, 1964) and some were identified subsequently from Kazhakstan (e.g., Ergaliev 1983) and elsewhere (e.g., Ludvigsen \& Westrop in Ludvigsen et al. 1989). Peng \& Babcock (2005), who provide a useful compilation of images, considered most of these to be junior synonyms of L. americanus (Billings) but, as discussed later under that species, we cannot endorse their conclusions.

Troedsson (1937) described two new species, Agnostus hedini and Lotagnostus asiaticus from Kuruktagh, Xinjiang, northwestern China; the former species will be discussed separately later. The holotype of L. asiaticus is a complete exoskeleton (Treodsson 1937, pl. 1, fig. 10a, b; Peng \& Babcock 2005, fig. 2.12), which apparently has a relatively weakly furrowed glabella and distinct trisection of the pygidial posteroaxis expressed by shallow notular furrows. The external surface of the holotype is nearly smooth, but the paratypes include more strongly furrowed cephala (Troedsson 1937, pl. 1, figs 14, 15) with well-defined anastomosing scrobiculation, much like cephala of its possible synonym, L. spectabilis Xiang \& Zhang, 1985, which is also from Xinjiang. Material from Zejiang attributed to L. asiaticus by $\mathrm{Lu} \& \mathrm{Lin}(1980$, pl. 1, fig. 6; Lu \& Lin 1989, pl. 6, fig. 13, pl. 7, figs 1-3) includes both weakly furrowed, lightly scrobiculate cephala and strongly scrobiculate, well-furrowed specimens. From an examination of the holotype, Peng \& Babcock (2005, p. 112) concluded that the absence of sculpture on the external surface was the result of weathering (see also Lu \& Lin 1989, p. 215). However, Troedsson (1937, p. 25) noted that some specimens "have been prepared free from rock in the museum and now show a smooth test with only shallow furrows and slightly prominent lobes". The specimens with well-developed furrows and scrobiculation are exfoliated and, according to Troedsson (1937, p. 25), the scrobiculation "seems to be due to a sculpture below the test". In any event, the well-developed glabellar furrows and scrobiculation on internal moulds of the cephalon separate $L$. asiaticus from both $L$. cf. L. trisectus and L. germanus.

Lotagnostus punctatus Lu, 1964, was first described from western Zejiang but has since been reported from other regions in southeastern China (e.g., Peng 1984, 1992) and Kazakhstan (Ergaliev 1983). The holotype (Peng \& Babcock 2005, fig. 2.13) and other sclerites from the type area (Lu \& Lin 1989, pl. 6, figs 8-12) are mostly flattened to varying degrees. However, a cephalon preserved in full relief (Lu \& Lin 1989, pl. 6, fig. 8) shows that F2 is firmly impressed and that the basal lobes are relatively long. An uncompacted pygidium has conspicuous trisection of the posteroaxis, with deep notular furrows that contain notulae. Similar features are evident in sclerites from Hunan that were assigned to L. punctatus by Peng (1992, e.g., figs 6B, C, E, G). All of the character states listed above separate $L$. punctatus from $L$. cf. $L$. trisectus. The former is quite similar to L. asiaticus but is differentiated by the far more strongly expressed trisection of the posteroaxis. Lu \& Lin (1989, p. 215) mention a weakly impressed preglabellar median furrow and the presence of pitted sculpture on the pygidial pleurae (e.g., see Peng \& Babcock 2005, fig. 2.23) as other diagnostic characters of L. punctatus, although these traits are not developed uniformly in sclerites from Hunan (e.g., Peng 1992, pl. 6, figs 6B, D). Finally, we note that sclerites from Kazakhstan that were attributed to both L. punctatus and L. asiaticus by Ergaliev (1983, pl. 1, figs 1-5 and figs 6, 7, 9, respectively) are too poorly preserved for a confident identification.

\section{Lotagnostus germanus (Matthew, 1901) Figure 4}

1901 Agnostus trisectus mut. germanus Matthew; Matthew, p. 279.

1903 Agnostus trisectus mut. germanus Matthew, 1901.Matthew, p. 221.

Diagnosis. - Lotagnostus with ill-defined F2 glabellar furrows and M3 lobes. Pygidial posteroaxis with barely perceptible trisection. Pygidial margins and flanks of the acrolobe converge backward, so that the pygidial outline is relatively narrow.

Lectotype. - A pygidium (NBMG 3358; Fig 4D-F) from the middle Chesley Drive Group collection by W.D. Matthew along the north shore of East Bay near Eskasoni, Cape Breton Island, Nova Scotia.

Discussion. - Lotagnostus germanus is sufficiently similar to L. cf. L. trisectus that the comparison presented above, under the discussion of the latter, makes a full description unnecessary. Among non-effaced species, the 
poorly defined F2 glabellar furrows and M3 lobes are apparently character states that are unique to Avalonian Lotagnostus.

The poorly defined intranotular axis on the posteroaxis is also a characteristic of Lotagnostus subtrisectus Westergård, 1944 (pl. 1, fig. 2). Unfortunately, this unique sclerite, which was recovered from drill-core, is apparently flattened in shale, so we cannot be sure whether the similarities with L. germanus are simply taphonomic in nature. For this reason, we have not included it in the above synonymy listing.

\section{Lotagnostus americanus (Billings, 1860)}

Figures 5, 6

1860 Agnostus americanus Billings; Billings, p. 303, figs $1 \mathrm{a}, \mathrm{b}$ [page number misprinted as 203].

1865 Agnostus americanus Billings, 1860. - Billings, p. 395, fig. 372a, b.

1944 Agnostus americanus Billings, 1860. - Rasetti, p. 233, pl. 36, figs $1,2$.

1989 Lotagnostus americanus (Billings, 1860). - Ludvigsen \& Westrop in Ludvigsen et al., p. 11, figs 15, 16 [only; fig. $17=$ L. sp. indet.].

non 1995 Lotagnostus americanus (Billings, 1860). - Westrop, p. 15 , figs $17-20$ [= L. sp. indet.].

2005 Lotagnostus americanus (Billings, 1860). - Peng \& Babcock, p. 110, figs 2.2-2.4 [only].

non 2008 Lotagnostus americanus (Billings, 1860). - Lazarenko et al., pl. 23, figs 1, 2, 5, 5a.

2009 Lotagnostus americanus (Billings, 1860). - Rushton, p. 276 , fig. $1 \mathrm{~J}-\mathrm{O}$.

Diagnosis. - Lotagnostus with weakly scrobiculate cephalon partly effaced externally but with weakly convex glabella well defined on internal mould; short basal glabellar lobes terminate well short of level of axial node. Distinct median indentation of acrolobe at anterior tip of preglabellar median furrow. Pygidial acrolobe gently constricted. F1 furrows not connected across axis. Posteroaxis long; trisection weakly developed, with intranotular axis recognizable primarily by change in slope medially, and may be absent altogether in small individuals.

Occurrence. - Cambrian (Sunwaptan) boulders in conglomerates of the Lévis Formation, North Ridge (Rasetti, 1944), Lévis, Quebec.
Description. - Cephalon semi-elliptical in outline, width equal to about 90 percent (86-92) of length, and strongly convex in lateral and anterior views. Acrolobe very slightly constricted with weak indentation at anterior tip of preglabellar median furrow. Glabella gently convex along anteroglabella and M3, but more elevated along rest of posteroglabella; apparently outlined fully on dorsal surface of exoskelton (Fig. 6H-J) by finely etched axial furrows, but segmentation (aside from basal lobes) poorly expressed. Glabellar furrows and lobes better defined on internal mold. Excluding basal lobes, glabella nearly parallel-sided, slightly expanded at M3, and with rounded anteroglabella; occupies about 70 percent (67-74) of cephalic length and a little more than a third (35 percent; $34-36$ ) of cephalic width. Basal lobes short, equal to about one-quarter (24 percent; 23-26) of glabellar length, and subtriangular in outline. Basal furrows shallow on external surface but deeper on internal mould; curve abruptly outward at posterior, becoming weakly divergent anteriorly, so that basal lobes not "notched" into posteroglabella. Median body of posteroglabella subrectangular in outline. Shallow F2 furrow nearly transverse near axial furrow, but faint extension curves forward, reaching F3 in some specimens, so that M3 is tripartite, with subcircular lateral lobes. Axial node located roughly midway between the level of anterior tips of basal lobes and M3; smaller medial node present at posterior tip of posteroglabella (Fig. 5F). Transglabellar furrow (F3) finely etched and nearly transverse medially but deflected forward abaxially around anterior edges of M3 lateral lobes. Anteroglabella conspicuous and long, occupying slightly more than one-third (36 percent; 33-38) of glabellar length. Complete preglabellar median furrow present on all specimens, but shallower on smallest (Fig. 6C). Border furrow well impressed into edge of acrolobe, but passes laterally to border with only change in slope. Posterior border with maxiumum length (exsag.) near basal lobe, at conspicuous triangular extension (Fig. 6H, J), but narrows abaxially. Lateral border widens conspicuously from posterior corner of cephalon to point opposite F2, then maintains roughly even width to anterior end of cephalon. External surface with faint scrobiculation, but better defined on internal mould.

Pygidium known only from internal mould. Convex pygidium semielliptical in outline, length (excluding articulating half-ring) a little more than 90 percent $(93$; 91-95) of width, with axis raised well above genal field; acrolobe constricted. Axis outlined by finely etched axial furrows and occupies about 85 percent $(84 ; 82-85)$ of pygidial

Figure 4. Lotagnostus germanus (Matthew, 1901), from the middle Chesley Drive Group ("MacNeil Formation”), north shore of East Bay near Eskasoni, Cape Breton Island, Nova Scotia. • A-C - cephalon, dorsal, lateral and anterior views, NBMG 15453 (paralectotype), $\times 9$. $・$ D-F - pygidium, posterior, lateral and dorsal views, NBMG 3358 (lectotype), $\times 12$. $\bullet$ G-I - cephalon, lateral, anterior and dorsal views, NBMG $4373, \times 12$. - J-L - cephalon, anterior, lateral and dorsal views, NBMG 15454, ×15. • M-O - pygidium, lateral, posterior and dorsal views, NBMG $15455, \times 18$. 

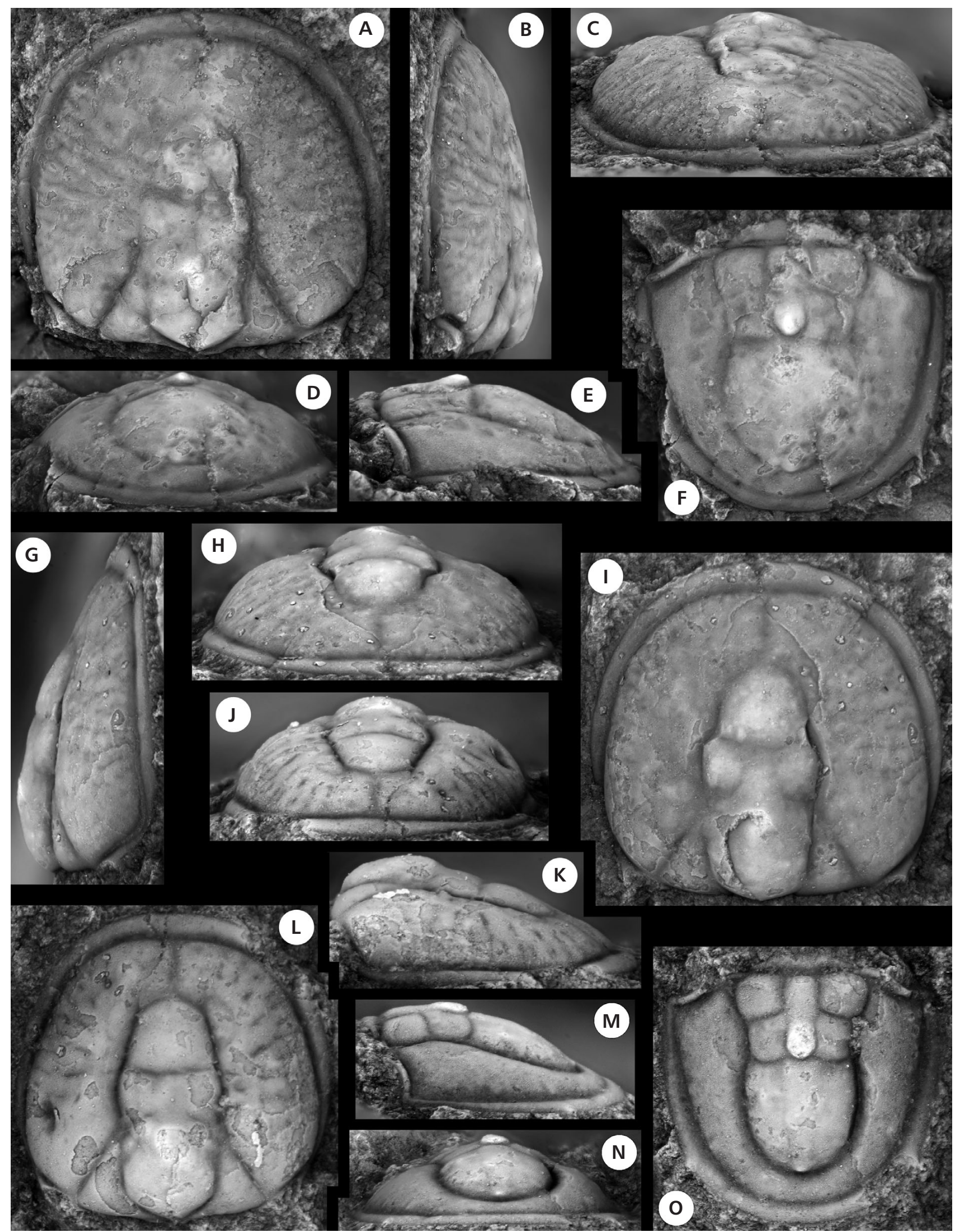

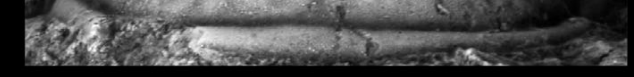

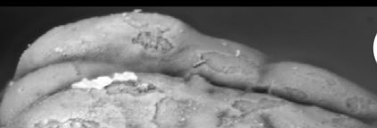

(K)

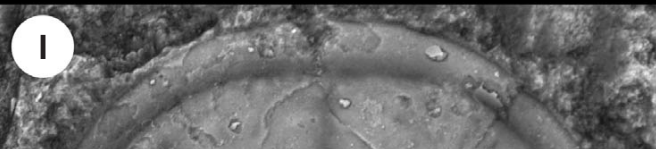

\section{3}
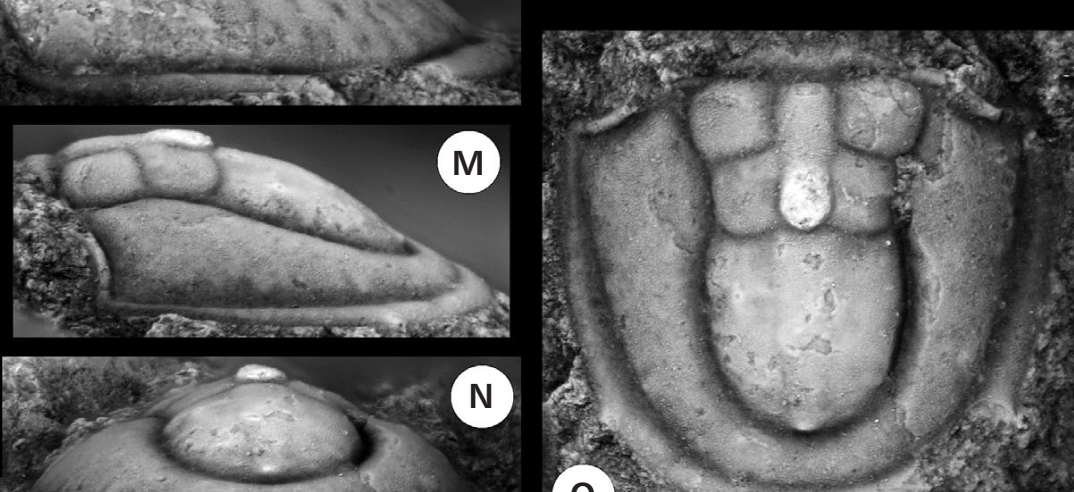

(N)

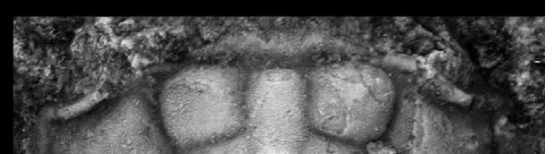

(1)

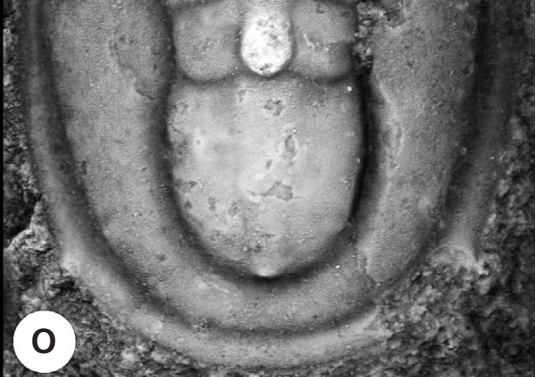


length and 40 percent $(41 ; 39-44)$ of pygidial width; slightly constricted at M2, with width at F2 equal to 80 percent (78-83) of width at mid-point of $\mathrm{M} 1$, and rounded posteriorly. Articulating furrow well-defined, nearly transverse; axial recess absent; articulating half-ring transversely sub-elliptical in outline. Anteroaxis occupies about half (51 percent; 47-53) of axis length (excluding articulating half-ring). F1 extends slightly oblique forward from axial furrow, then deflected anteriorly to articulating furrow; F2 transverse and connected across axis. M1 and M2 tripartite, roughly equal in length (exsag.) and with subquadrate lateral lobes; central median lobe extends uninterrupted from articulating furrow to $\mathrm{F} 2$ and elevated into large axial node at M2. Posteroaxis with weakly defined intranotular axis on larger specimens, with faint notular furrows, with node at posterior end; only node present in smaller specimens. Pleural field gently inflated and slopes steeply downward, flattening at border; border furrow expressed largely as change in slope. Minute posterolateral spine present just in front of level of posterior tip of axis. Pleural field smooth to weakly scrobiculate.

Discussion. - Rushton (2009) recently reviewed L. americanus (Billings, 1860) using material assigned to that species by Rasetti (1944). He questioned the broad view of L. americanus proposed by Peng \& Babcock, which has been adopted by many recent authors (e.g., Terfelt et al. 2008, Lazarenko et al. 2008), and pointed to morphological differences between this species and such others as L. asiaticus Troedsson, 1937, and L. punctatus Lu, 1964, from China (see also Ludvigsen \& Westrop in Ludvigsen $e t$ al. 1989, p. 12) and L. trisectus (Salter, 1864). We agree with Rushton's assessment of L. americanus, which seems to be similar to the view of Ludvigsen \& Westrop (in Ludvigsen et al. 1989), although we see no reason why the distinction between it and L. trisectus should be expressed at the subspecific level, as proposed by Rushton. As discussed below, we consider L. trisectus, L. asiaticus, L. hedini (Troedsson, 1937), L. punctatus, and L. obscurus Palmer, 1955, among others, to be entirely separate species from L. americanus.

Rushton (2009, p. 276) also noted that Billings [(1860, p. 302 (figure caption)] questioned the assignment of his two cephala to L. americanus and, as a result, these specimens (GSC 859b, 859c) must be treated as topotypes rather than paratypes. Only one of these has been illustrated photographically in previous work (GSC 859c; Ludvigsen et al. 1989, pl. 1, fig. 16; reproduced by Peng \& Babcock 2005, fig. 2.4; Fig. 6H-J). However, as details of the anterior half of the glabella and the preglabellar median furrow are obscured in this somewhat weathered specimen, Billings' (1860, pp. 302, 303) description must have been based largely upon the other cephalon (GSC 859b; Fig. 5D-G). This specimen is exfoliated but is comparable in outline to the other, largely testate topotype; both are similar in the morphology and proportions of the posteroglabella and basal lobes, are weakly scrobiculate, and share a slight median indentation of the acrolobe at the anterior tip of the preglabellar median furrow. Details of the anatomy that can be seen clearly only in GSC 859 b include a shallow median preglabellar furrow that extends to the border furrow. This specimen also shows that the anterior lobe of the glabella is conspicuous and is rounded anteriorly. The transglabellar furrow (F3) is finely etched on this internal mould, and is nearly transverse medially but deflected forward abaxially. M3 is well-defined and tripartite on the internal mould, with a faint furrow extending from shallow F2 to F3. The axial node is located on the posteroglabella roughly midway between the level of the anterior tips of the basal lobes and M3, and an additional, smaller medial node is present at the posterior tip of the posteroglabella.

Rushton's (2009, fig. 1J-O) images of previously unfigured sclerites from Rasetti's (1944) boulder 37 include cephala that are very similar to Billings' specimens. Pygidia from boulder 37 have constricted acrolobes; trisection of the posteroaxis is weakly developed, and the intranotular axis recognizable primarily by a change in slope medially (Rushton 2009, fig. 1N). Billings' holotype pygidium is larger than either of those figured by Rushton, but is comparable in morphology, although the notular furrows are evident, albeit very weakly. The relative length, proportions and segmentation of the axis are very similar, as is the size and placement of the posterolateral spines (compare Rushton 2009, fig. 1M, N and Fig. 5A-C).

We were unable to secure a loan of the remaining unfigured material from Rasetti's boulder 37 that is currently housed in the Natural History Museum in London. We were, however, able to gain access to two specimens from the same boulder that are part of the type collections at the Geological Survey of Canada, Ottawa (Fig. 6A-G). One of these is an incomplete cephalon that was originally illustrated by Rasetti (1944, pl. 36, fig. 1; reproduced by Peng \& Babcock 2005, fig. 2.3). In Rasetti's photograph, this sclerite is lit harshly from the upper left and strong shadows create a misleading impression of the depth of the glabellar furrows and the scrobiculation. Our new images (Fig. 6E-G) indicate that the density of the scrobiculation is a little greater than in the other cephala illustrated by Rushton, but the depth of the furrows and the segmentation pattern of the glabella are comparable. Rasetti's photograph was cropped to the apparent margin of the specimen but our image shows that a segment of the border at the left posterior corner was inadvertently trimmed away. The rest of the posterior margin is covered by matrix but the position the posterior corner indicates that nearly a third of the basal lobes and a significant part of the posteroglabella are obscured. 

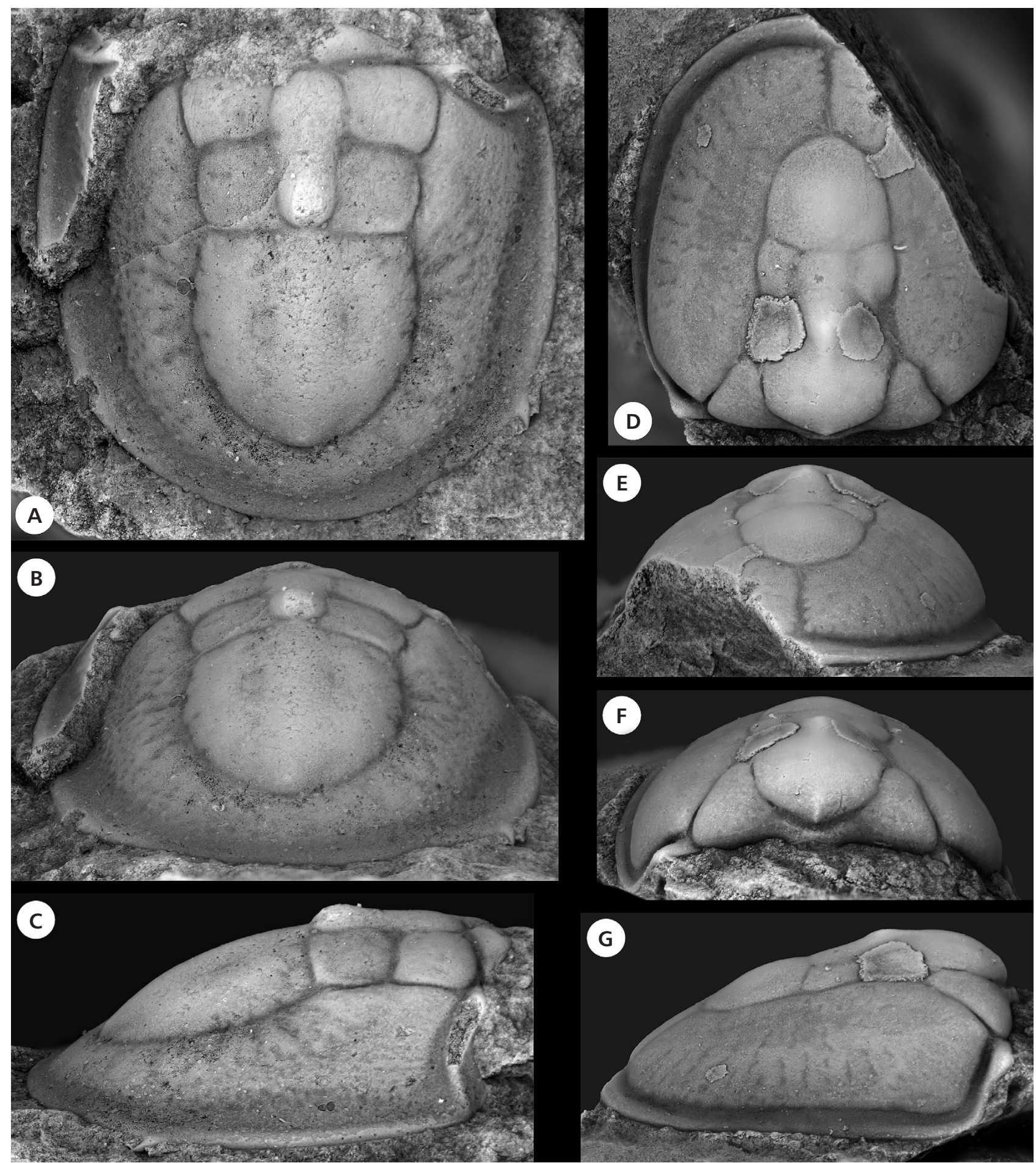

Figure 5. Lotagnostus americanus (Billings, 1860) from the Lévis Formation, North Ridge, Lévis, Quebec. • A-C - pygidium, dorsal, posterior and lateral views, GSC 859 (holotype, by monotypy, see Rushton 2009, p. 276), × 12. • D-G - cephalon, dorsal, anterior, posterior and lateral views, GSC 859b (topotype; see Rushton 2009, p. 276).

The other specimen from boulder 37 (Fig. 6A-D) is a small, enrolled individual that was mentioned by Rasetti (1944, p. 233) but, curiously, was left unillustrated. Aside from a relatively shorter glabella, the cephalon (Fig. 6B-D) is comparable to Billings' best preserved topotype of L. americanus (Fig. 5D-G) and to other cephala figured by Rushton (2009). The pygidial axis (Fig. 6A) is a little shorter and narrower than the much larger holotype 
pygidium but agrees in the constricted acrolobes, expression of the furrows, and proportions of the various lobes of the axis. There is, however, no trace of the trisection of the posteroaxis (Fig. 6A, B, D).

Given the strong similarities discussed above, we provisionally include Billings' topotypes and various figured specimens from Rasetti's boulder 37 in Lotagnostus americanus (see also Rasetti 1944, p. 233). All of this material is from boulders that are correlative with the Keithia subclavata Fauna of western Newfoundland (Ludvigsen \& Westrop in Ludvigsen et al. 1989). We agree with Rushton (2009, p. 278) that a cephalon (Ludvigsen et al. 1989, pl. 1, fig. 17) from a younger boulder in Newfoundland (BPC 290; Phylacterus saylesi Fauna) should be excluded from L. americanus, although rather than following Rushton in assigning it to L. trisectus, we consider it to be of uncertain status.

Poorly defined trisection of the pygidial posteroaxis that may be absent altogether in smaller specimens is a characteristic of L. americanus. In this respect, it approaches the morphology of L. hedini (Troedsson, 1937), which lacks trisection across a wide size range. This species will be discussed in detail below, but all pygidia that have been attributed to it by various authors (e.g., Troedsson 1937, pl. 1, figs 6-8; Apollonov et al. 1984, fig. 14; Lu \& Lin 1989, pl. 7, figs 5, 8; Ludvigsen et al. 1989, pl. 1, figs 3, 4, 7, 8, 11) are differentiated from $L$. americanus by relatively longer axes that terminate close to the border furrows, and F1 furrows that are connected across the axis. Like those of L. americanus, cephala assigned to L. hedini are weakly scrobiculate. There are few other consistent differences between cephala of these species, although Troedsson's (1937, pl. 1, fig. 6) holotype from Xinjiang and other specimens from western Zhejiang (Lu \& Lin 1989, pl. 7, figs 6, 7) have longer basal lobes that extend forward almost to the level of the axial node.

Published images of sclerites of Lotagnostus peladensis (Rusconi 1951; Shergold et al. 1995, pl. 1, figs 1-9) from the Argentine Precordillera show variation in outline that may reflect minor tectonic shortening or shear. Pygidia are similar to those of L. americanus, differing in apparently lacking any trace of trisection of the posteroaxis even in larger specimens. Cephala are less effaced than L. americanus and, unlike the latter, there is little difference in the expression of various furrows and glabellar lobes between testate and exfoliated surfaces. Lotagnostus attenuatus (Rusconi 1955; Shergold et al. 1995, pl. 1, figs 10, 11), also from the Precordillera, is based on limited material but is apparently differentiated from $L$. americanus by its shorter axis with well-defined trisection of the posteroaxis.

As discussed by Ludvigsen \& Westrop (in Ludvigsen $e t$ al. 1989, p. 12), cephala of Lotagnostus americanus are differentiated from those of $L$. asiaticus Troedsson and L. punctatus Lu in possessing much shorter basal glabellar lobes. They also stated that pygidia of these three species were indistinguishable. Peng \& Babcock (2005, p. 112) apparently misinterpreted this remark to indicate that Ludvigsen \& Westrop considered all three species to be synonyms. However, the authors' intent is clear from the fact that they did not include L. asiaticus and L. punctatus in the synonymy list for L. americanus (Ludvigsen et al. 1989, p. 12). Moreover, with additional material that was not available to Ludvigsen and Westrop (Fig. 6A-D; Rushton 2009, fig. 1M-O), it is now evident that both L. asiaticus and, especially, L. punctatus are characterized by greater development of the trisection of the posteroaxis (Troedsson 1937, pl. 1, figs 10-13; Lu \& Lin 1989, pl. 7, fig. 3; Peng \& Babcock 2005, fig. 2.13, 2.14, 2.22, 2.23), which includes deeper notular furrows that, in the latter, are augmented by conspicuous notulae; L. americanus also lacks the punctate sculpture that is expressed on the pleurae of L. punctatus.

Comparisons with neotype and topotype Lotagnostus trisectus (Salter; Rushton 2009, fig. 1A-I, P) are difficult because of effects of compaction on these flattened specimens. At the very least, trisection of the pygidial posteroaxis is better defined in L. trisectus, and we agree with Rushton (2009, p. 277) that the basal glabellar lobes of this species are relatively longer than those of L. americanus. Trisection of the pygidial posteroaxis is also better expressed in Lotagnostus cf. L. trisectus from Nova Scotia (Figs 2, 3A-C) and, unlike L. americanus, the pygidial acrolobe is unconstricted. On the cephalon of $L$. cf. L. trisectus (Fig. 3D-G), F2 and M3 are barely recognizable and the axial node is farther back on the glabella, opposite the anterior tips of the basal lobes, which appear to be larger than those of L. americanus. Similarly, L. "trisectus" as illustrated from Sweden (Rushton 2009, fig. 1E, F, H-J) and Siberia (Pegel 2000, fig. 15.6, 15.10) is clearly differentiated from L. americanus by the strongly defined trisection of the pygidial posteroaxis and by longer basal glabellar lobes that are notched into the posteroaxis behind M2.

Ludvigsen \& Westrop (in Ludvigsen et al. 1989, Westrop 1995) considered Lotagnostus obscurus Palmer 1955 , to be a junior synonym of $L$. americanus but, as discussed later in this paper, restudy of the types of the former

Figure 6. Lotagnostus americanus (Billings, 1860) from the Lévis Formation, North Ridge, Lévis, Quebec. All × 12.・A-D - enrolled exoskeleton, dorsal view of pygidium, lateral view, dorsal view of cephalon, anterior view of cephalon and posterior view of pygidium, GSC 134619 (previously unfigured specimen mentioned by Rasetti 1944, p. 233), boulder 37. • E-G - cephalon, lateral, dorsal and anterior views, GSC 134620 (previously illustrated by Rasetti 1944, pl. 36, fig. 1), boulder 37. • H-J - cephalon, dorsal, anterior and lateral views, GSC 859c. 


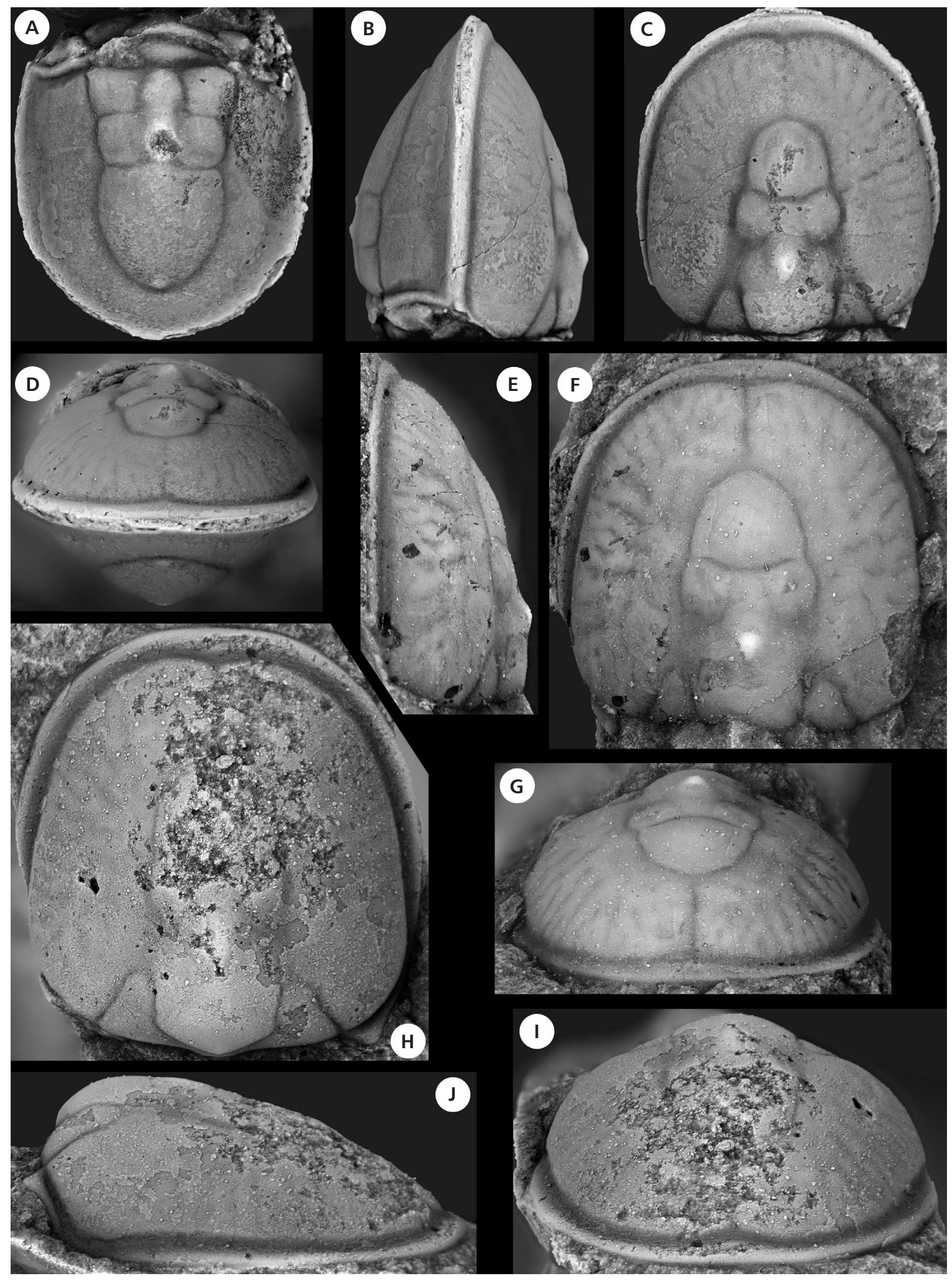


leads us to conclude that they are better treated as separate species.

\section{Lotagnostus hedini (Troedsson, 1937)}

1937 Agnostus hedini Troedsson; Troedsson, p. 20, pl. 1, figs 6-8.

1980 Lotagnostus hedini (Troedsson, 1937). - Lu \& Lin, p. 124, pl. 1, figs 8, 9 .

1984 Lotagnostus hedini (Troedsson, 1937). - Apollonov et al., pl. 14, figs 1-8.

1984 Lotagnostus hedini (Troedsson, 1937). - Lu \& Lin, p. 63, pl. 3, figs $12,13$.

1989 Lotagnostus hedini (Troedsson, 1937). - Lu \& Lin, p. 93, pl. 7, figs 4-8.

?1989 Lotagnostus hedini (Troedsson, 1937). - Ludvigsen \& Westrop in Ludvigsen et al., p. 12, pl. 1, figs 9-11 [only; figs 1-8, 12-14 = Lotagnostus spp. indet.].

non 2000 Lotagnostus hedini (Troedsson, 1937). - Pegel, figs 15.8., 15.12.

non 2008 Lotagnostus hedini (Troedsson, 1937). - Lazarenko et al., pl. 21, figs 1, 2, pl. 23, figs 4, 5 .

Diagnosis. - Lotagnostus with conspicuous basal lobes on glabella that extend forward to point opposite median node. Long pygidial axis with smooth, non-trisected posteroaxis that occupies more than half of axial length; F1 furrows are curved forward and are connected across the axis; M2 subpentagonal in outline. Pygidial acrolobe constricted, strongly so on larger individuals.

Occurrence. - Kuruktagh, Xinjiang, northwestern China (Troedsson 1937); Batyrbai Section, Kazakhstan, Euloma limitaris-Taoyuania Zone (Apollonov et al. 1984, 1988); Siyangshan Formation, western Zhejiang, China, Lotagnostus hedini Zone (Lu \& Lin 1980, 1984, 1989); ?Shallow Bay Formation, western Newfoundland, Phylacterus saylesi Fauna (Ludvigsen et al. 1989).

Discussion. - In Laurentia, Lotagnostus hedini has been reported from the Gorge Formation at Highgate Gorge, Vermont, and from the Shallow Bay Formation in western Newfoundland (Ludvigsen \& Westrop in Ludvigsen et al. 1989). As discussed below, there are differences between sclerites illustrated from individual collections that raise doubts as to whether these Laurentian occurrences record a single species. As far as we are aware, Troedsson's (1937, pl. 1, figs 6-8), original material has not been revised, although Apollonov et al. (1984, pl. 14, fig. 4) provide an apparently new dorsal view of the holotype exoskeleton.

Troedsson's types comprise two exoskeletons (one of which - pl. 1, fig. 7- is somewhat weathered) and an incomplete pygidium. As far as we can determine from published photographs, F2 and transglabellar F3 furrows are well-incised on the glabella, so that the M3 lobe is clearly expressed. Axial furrows appear to be well defined and a preglabellar median furrow is present. The pygidial axis is long, terminating close to the border furrow, and there is no trace of trisection on the posteroaxis; F1 is connected across the axis in all specimens. Apollonov et al.'s new image of the holotype indicates that the pygidial acrolobe is constricted. The best preserved cephalon of L. hedini is part of the holotype exoskeleton. It has a conspicuous, wellrounded anteroglabella and relatively large basal lobes that extend forward to a point opposite the axial node.

Apollonov et al. (1984, pl. 14, figs 1-3) also illustrated complete exoskeletons from the Batyrbay section in Kazakhstan that closely resemble Troedsson's type and which were identified as L. hedini. Large pygidia from this section (Apollonov et al. 1984, pl. 14, figs 7, 8) differ from smaller specimens only in their more strongly constricted acrolobes, suggesting that the expression of this trait may be a function of size. Ergaliev's (1983, pl. 1, figs 10-14) report of $L$. hedini from southern Kazakhstan is based on deformed sclerites that are too poorly preserved for critical evaluation.

Lotagnostus hedini has also been reported from the Chinese province of Zhejiang (Lu \& Lin 1980, 1989). Cephala from this region differ from specimens from the Batyrbay section only in their shallower preglabellar median furrows (e.g., compare Lu \& Lin 1989, pl. 7, figs 6, 7 and Apollonov et al. 1984, pl. 14, fig. 8). The pygidia (e.g., Lu \& Lin 1989, pl. 7, figs 5, 8) share several features with Troedsson's types and specimens from Kazakhstan, including a long axis with smooth, non-trisected posteroaxis that occupies more than half of axial length, and F1 furrows that are curved forward and are connected across the axis. Like larger pygidia from Batyrbay, they possess strongly constricted acrolobes. There is some variability in pygidial outline in specimens from Zhejiang, but we provisionally accept them as conspecific with the types from Xinjiang and other material from Batyrbay.

We are uncertain about the status of Lotagnostus hedini suspectus Xiang \& Zhang, 1985 (pl. 9, figs 8-12) from the Guozigou Formation, Xinjiang. Ludvigsen \& Westrop (in

Figure 7. Lotagnostus obscurus Palmer, 1955, from "Pogonip limestone unit 1" (probably Windfall Formation), Eureka, Nevada (USGS collection CO 790). All $\times 12$. $\bullet$ A-C - cephalon, lateral, anterior and dorsal views, USNM 123557a (paratype). • D-F - pygidium, dorsal, lateral and posterior views, USNM 123556 (holotype). • G-I - cephalon, dorsal, lateral and anterior views, USNM 123557b (paratype). 


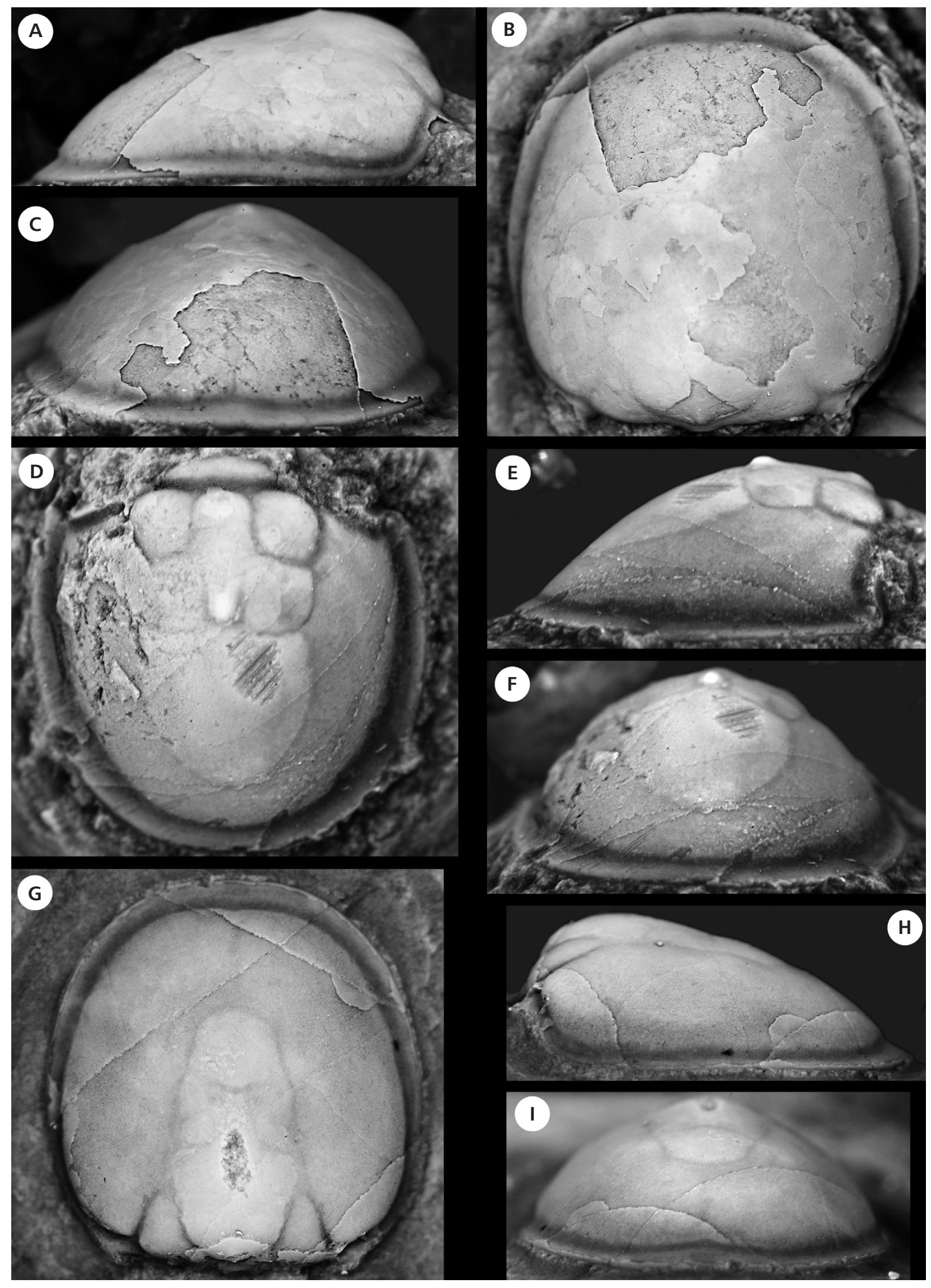


Ludvigsen et al. 1989, p. 12) included this subspecies in their synonymy of $L$. hedini without discussion. It appears to possess a relatively narrow pygidium with an acrolobe that is weakly constricted at best. It may be distinct from L. hedini but a decision must be deferred until additional material is available.

Ludvigsen et al. (1989) illustrated sclerites from the "Main Zone" of the Gorge Formation and from two boulders of different ages from conglomerates of the Shallow Bay Formation. Each of these samples is characterized by distinct morphotypes, although all three share the long pygidial axis with a smooth, undifferentiated posteroaxis and transaxial $\mathrm{F} 1$ furrow that is also evident in material from China and Kazakhstan. Indeed, Ludvigsen \& Westrop (in Ludvigsen et al. 1989, p. 12) included these characters in their revised diagnosis of $L$. hedini. However, if a constricted pygidial acrolobe is also a diagnostic character state of this species, then only one of these morphotypes, from boulder BPC 290, which belongs in the basal Ibexian Phylacterus saylesi Fauna, is has any likelihood of recording L. hedini. A pygidium (Ludvigsen et al. 1989, pl. 1, fig. 11) from this boulder is strikingly different from the others from eastern Laurentia in possessing strongly constricted acrolobes. It is, however, not unlike pygidia from Zhejiang (Lu \& Lin 1989, pl. 7, figs 5, 8) and Batyrbay (Apollonov et al. 1984, pl. 14, figs 7, 8) in this regard although all specimens from the latter two regions are distinct in having F1 furrows that are deflected strongly forward instead of being nearly transverse, so that M2 is subpentagonal in outline, rather than subrectangular. The associated cephalon is similar to those from Kazakhstan and China, differing primarily in having an axial node that is farther forward on the posteroaxis, immediately behind F2 (e.g., compare Ludvigsen et al. 1989, pl. 1, fig. 9 with Apollonov et al. 1984, pl. 14, fig. 5). While it is possible that material from BPC 290 is conspecific with L. hedini, the assignment should be considered as questionable until sufficient material is available to evaluate significance of the morphologic differences described above.

The remaining sclerites illustrated by Ludvigsen et al. (1989, pl. 1, figs 1-8, 12-14) are from older collections that were assigned to the upper Sunwaptan Keithia schucheri Fauna. The pygidia from Vermont (Ludvigsen et al. 1989, pl. 1, figs 3, 4, 7, 8) have unconstricted acrolobes, which immediately differentiates them from material from China, Kazakhstan and boulder BPC 290. The pygidial axes also appear to be proportionately wider. Apart from somewhat smaller basal lobes, we can see little difference between the associated cephala (Ludvigsen et al. 1989, pl. 1, figs $1,2,5,6,7)$ and L. hedini. Only three sclerites were illustrated from boulder BPN 240 from the Shallow Bay Formation (Ludvigsen et al. 1989, pl. 1, figs 12-14). The cephalon is distinctive in having lateral margins that converge markedly forward, so that it is relatively narrow anteriorly. The two associated pygidia are small, but have essentially parallel-sided axes, rather than being constricted at M2 as in other specimens attributed to L. hedini (e.g., Apollonov et al. 1984, pl. 14, fig. 7; Lu \& Lin 1989, pl. 7, figs 5,8). We doubt that these are conspecific with any other Lotagnostus material from Laurentia or from Kazakhstan and China.

In recent years, L. hedini has been reported from Member V of the Ogon'or Formation along the Khos-Nelege River of Siberia (Pegel 2000, Lazarenko et al. 2008). Lazarenko et al. (2008) illustrated a cephalon and pygidium from each of two different stratigraphic levels, but they do not appear to represent a single species, and neither pair of sclerites is conspecific with $L$. hedini from China or Kazakhstan. Sclerites (Lazarenko et al. 2008, pl. 23, figs 3, 4) from the younger occurrence, in the "L. americanus Zone" are relatively long and narrow, and the pygidial acrolobe is unconstricted; in contrast to pygidia from China, Kazakhstan and Newfoundland, F1 is not connected across the axis, so that an inflated medial band extends uninterrupted across M1 and M2. Unlike L. hedini, the basal lobes of the associated cephalon are notched behind a well-defined M2, and the preglabellar median furrow terminates short of the border furrow. The older pygidium (Lazarenko 2008, pl. 21, fig. 5; Pegel 2000, fig. 15.12), from the Parabolinites rectus Zone, is crushed, but appears have a gently constricted acrolobe; like the younger specimen, F1 is not connected across the axis. The associated cephalon (Lazarenko 2008, pl. 21, fig. 1) is broken posteriorly, but appears to be relatively broader and has shorter basal lobes; the preglabellar median furrow extends to the border furrow.

As noted by Shergold et al. (1995, p. 246, pl. 1, figs 1-9), L. peladensis (Rusconi 1951), from the Argentine Precordillera is quite similar to L. hedini, but differs in the structure of cephalic M2, and in having pygidial F1 furrows that are isolated by the median, inflated band that extends across M1 and M2 lobes. A second Argentinian species, Lotagnostus attenuatus (Rusconi 1955; Shergold et al. 1995, pl. 1, figs 10,11) is also distinguished from L. hedini in having isolated pygidial F1, and possesses clearly defined trisection of the posteroaxis.

Figure 8. Lotagnostus ergodes (Shergold, 1971) from the Gola Beds of western Queensland, Australia. • A-C - cephalon, dorsal, lateral and anterior views, CPC 9671 (paratype), $\times 15 . \bullet$ D-F - cephalon, lateral, anterior and dorsal views, CPC 9672 (paratype), $\times 18$. $\bullet$ G, H - pygidium, posterior and dorsal views, CPC 9670 (paratype) $\times 15$. $\bullet$ I - pygidium, dorsal view, CPC 9668 (paratype), × 18. • J-L - pygidium, posterior, lateral and dorsal views, CPC 9967 (holotype), $\times 18$. 


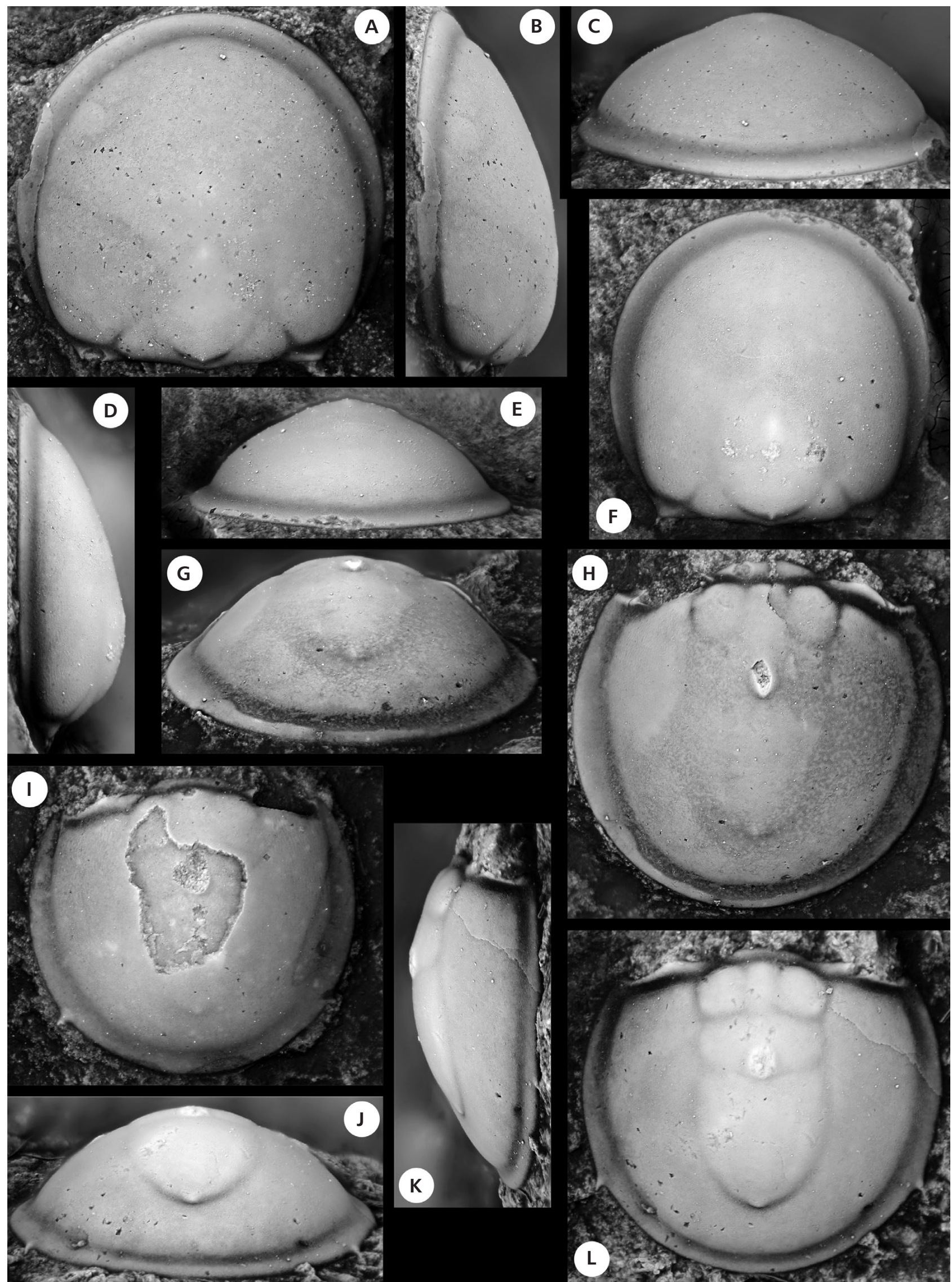




\section{Lotagnostus obscurus Palmer, 1955} Figure 7

1955 Lotagnostus obscurus Palmer; Palmer, p. 19, figs $5-7,10$.

non 2008 Lotagnostus obscurus Palmer. - Ergaliev \& Ergaliev, p. 46, pl. 42, figs 6-8.

Diagnosis. - Effaced, strongly convex Lotagnostus with segmentation of glabella and pygidial axis expressed fully only on ventral surface of exoskeleton. Cephalon with preglabellar median furrow poorly defined or absent even on internal mould. Pygidium with unconstricted acrolobe. F1 furrows do not connect across axis; nearly transverse at axial furrow but deflected anteriorly adxially to join articulating furrow, so that lateral lobes of M3 isolated. Faint intranotular axis evident only on small specimens.

Occurrence. - "Pogonip limestone, unit 1" (almost certainly Windfall Formation), 1400 feet S $28^{\circ}$ E of the Hamburg shaft (collection USGS 790 CO), Eureka District, Nevada (Palmer 1955). Palmer (1955, p. 87) considered that this species is "probably Franconia in age" (i.e. Lower Sunwap$\tan )$. The associated trilobite fauna has not been described, but a paratype (USNM 123557a) occurs on a small chunk of rock with an undescribed species of Bienvillia Clark, 1924, which suggests that it is no older than the Onchonotus richardsoni Fauna (e.g., see Ludvigsen et al. 1989, p. 15). This unit straddles the Lower-Upper Sunwaptan boundary, and is thus consistent with Palmer's assessment.

Discussion. - Ludvigsen \& Westrop (in Ludvigsen et al. 1989) considered L. obscurus to be a synonym of L. americanus (Billings), and this has been followed by most subsequent authors (e.g., Westrop 1995, Peng \& Babcock 2005). Restudy of sclerites from the type lot of L. obscurus (Fig. 7) indicates that it is a distinct species that is most similar to Australian material described by Shergold (1972, 1975; Figs 8, 9). Lotagnostus obscurus is clearly more effaced than L. americanus (Figs 5, 6; Rushton 2009, fig. 1J-O), with the preglabellar median furrow barely perceptible at best (Fig. 7G-I) even on internal molds of cephala, and all other furrows are noticeably shallower (compare similarly-sized exfoliated cephala shown in Figs $6 \mathrm{E}-\mathrm{G}$ and $7 \mathrm{G}-\mathrm{I})$. Although damaged by weathering, the largely testate topotype cephalon of $L$. americanus (Fig. 6H-J) demonstrates that the entire glabella is outlined on the external surface, whereas the glabella is defined weakly over only the posterior half of similarly-sized testate L. obscurus (Fig. 7A-C). Axial and other furrows of the pygidium are also shallower in large pygidia (Fig. 7D-F) but are somewhat better defined in smaller specimens (Palmer 1955, pl. 19, fig. 10), which also show weak trisection of the posteroaxis. The pygidial acrolobes of L. obscurus are unconstricted. Finally, sclerites of $L$. obscurus are strongly convex, particularly the pygidium, whereas those of L. americanus are less arched in both lateral and posterior views.

The strong convexity of cephala and pygidia of L. obscurus, as well as the grade of effacement, is matched in species from Australia that were assigned to "Distagnostus" by Shergold (1972; Figs 8, 9); indeed, Shergold (1972, p. 19) was also struck by the similarities between these taxa, and the distributional information provided by Shergold et al. (1990, p. 34) indicates that they regarded L. obscurus as a species of "Distagnostus". Like L. obscurus, external surfaces of cephala of L. ergodes (Shergold 1972; Fig. 8A-F) show complete effacement of the anterior half of the glabella along with the preglabellar median furrow, and the basal lobes are very short. On testate pygidia (e.g., Fig. 8I), the axis is outlined but segmentation is not evident; on internal molds (e.g., Fig. 8J-L), axial furrows, F1 and F2 are all expressed as very shallow grooves. Compared to L. obscurus, the pygidia are relatively wider with proportionately shorter and narrower axes; F1 is connected across the axis in at least smaller specimens (Fig. 8L).

Lotagnostus irretitus (Shergold 1975; Fig. 9) has a unique cephalic sculpture of very fine anastomosing lines that contrasts with the smooth external surface of $L$. $o b$ scurus. The pygidium (Fig. 9H, I) possesses a narrower and shorter axis, and the F1 furrows are connected rather than separated medially. In our view, the smaller of the two pygidia illustrated by Shergold (1975, pl. 14, fig. 5; Fig. 9J-L) is misassigned and likely belongs to a species of Micragnostus. The axis is far more convex and the axial furrows are deeper than in any other species of Lotagnostus. Although it is damaged anteriorly, M2 is clearly very long, and is equal to at least 60 percent of the length of the posteroaxis. This contrasts with the proportions of the other pygidium, in which $\mathrm{M} 2$ is equal to about 38 percent of posteroaxis length.

The identification of $L$. obscurus from the Sakian of Kazakhstan by Ergaliev \& Ergaliev (2008, pl. 42, figs 6-8) is puzzling as the figured sclerites show little resemblance

Figure 9. A-I - Lotagnostus irretitus (Shergold, 1975) from the "Chatsworth Limestone", Black Mountain, western Queensland, Australia. - A-C - cephalon, dorsal, lateral and anterior views, CPC 11518 (holotype), $\times 16$. - D-F - cephalon, lateral, anterior and dorsal views, CPC 11519 (paratype), $\times 15 . \bullet \mathrm{G}-$ cephalon, dorsal view, CPC 11521 (paratype), $\times 16 . \bullet \mathrm{H}, \mathrm{I}-$ pygidium, posterior and dorsal views, CPC 11520 (paratype), $\times 15$. - J-L-Micragnostus? sp. indet. from the "Chatsworth Limestone", Black Mountain, western Queensland, Australia; pygidium, posterior, dorsal and lateral views, CPC 11522 (originally assigned to L. irretitus by Shergold, 1975), $\times 16$. 

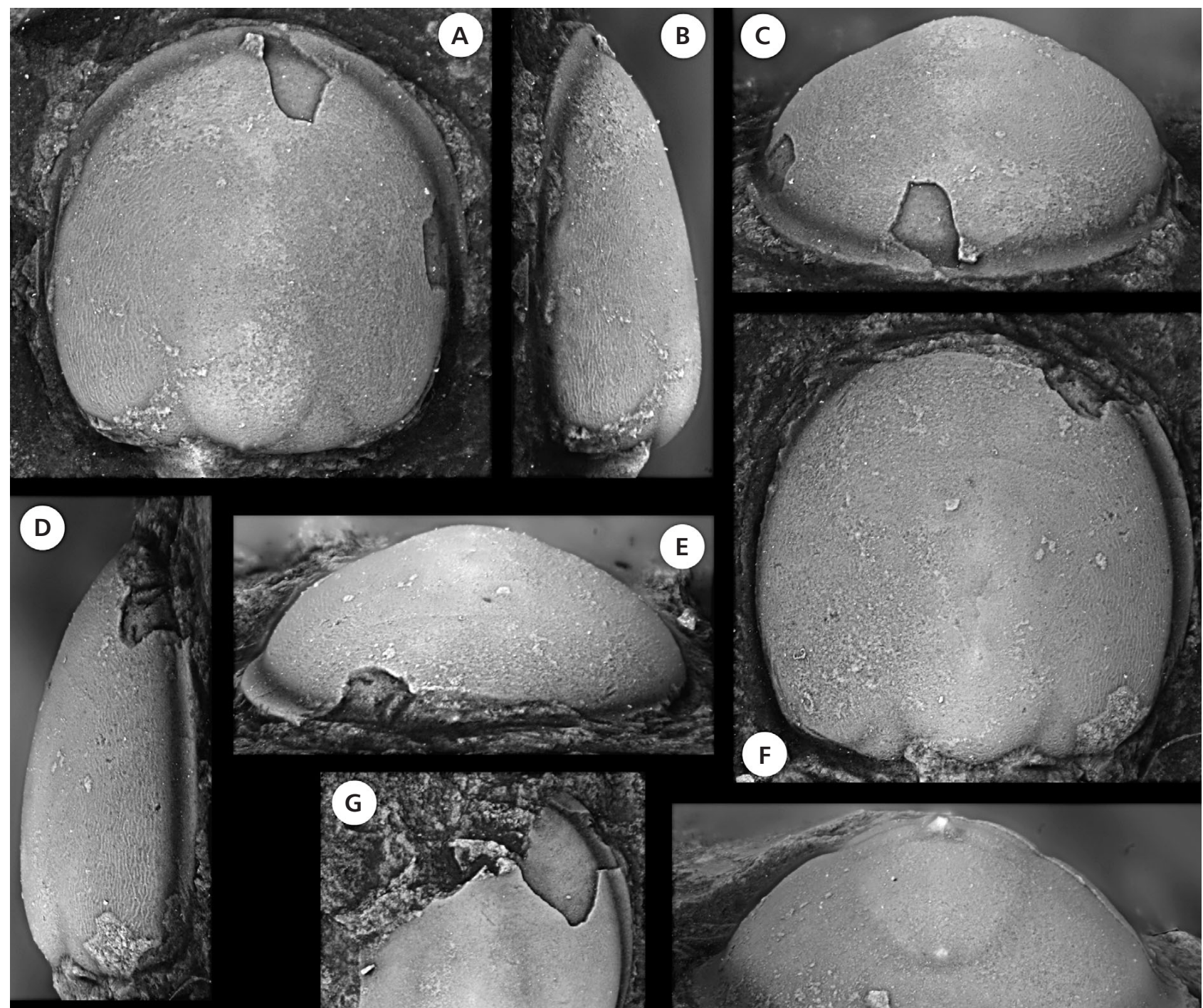

(J)
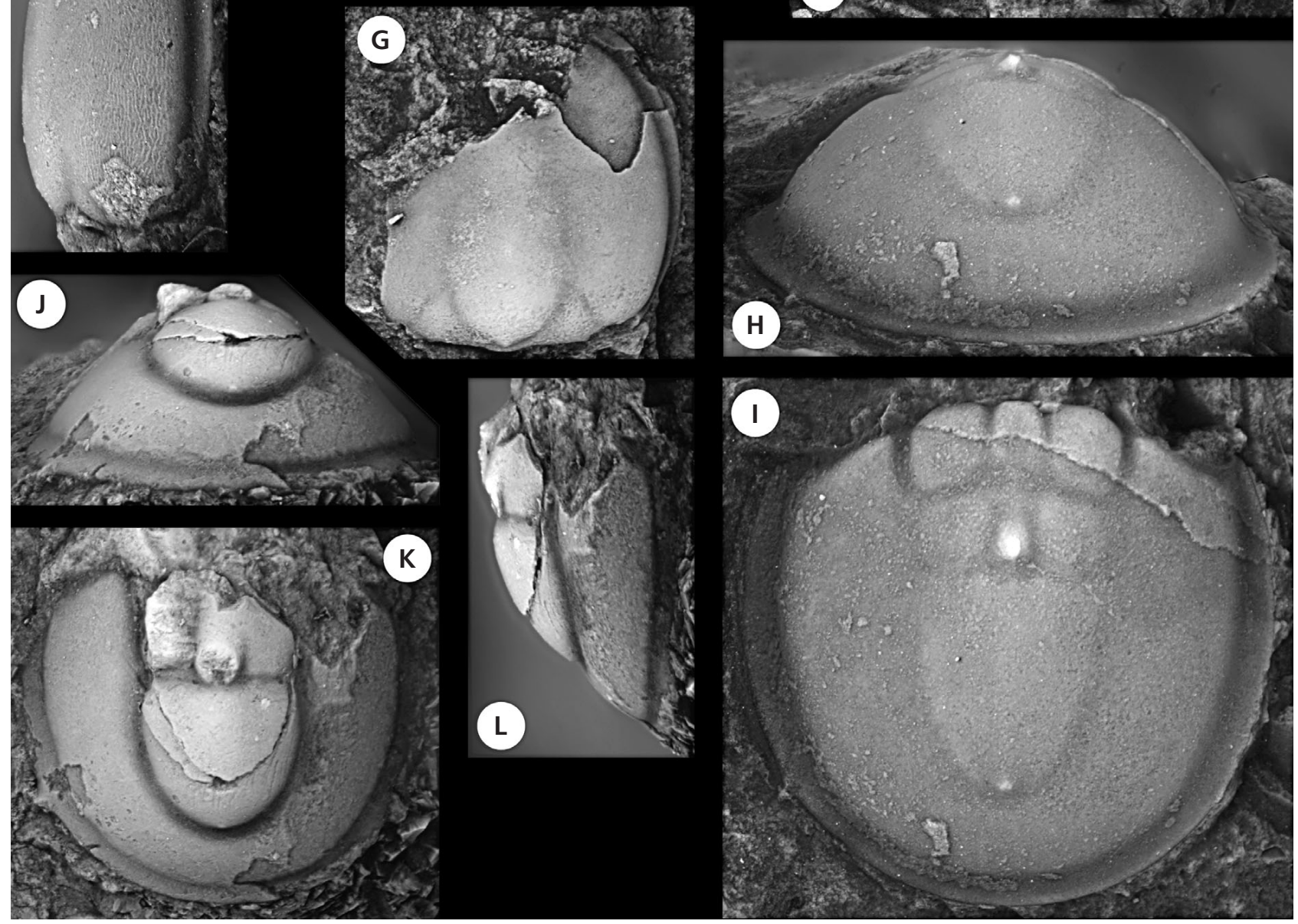


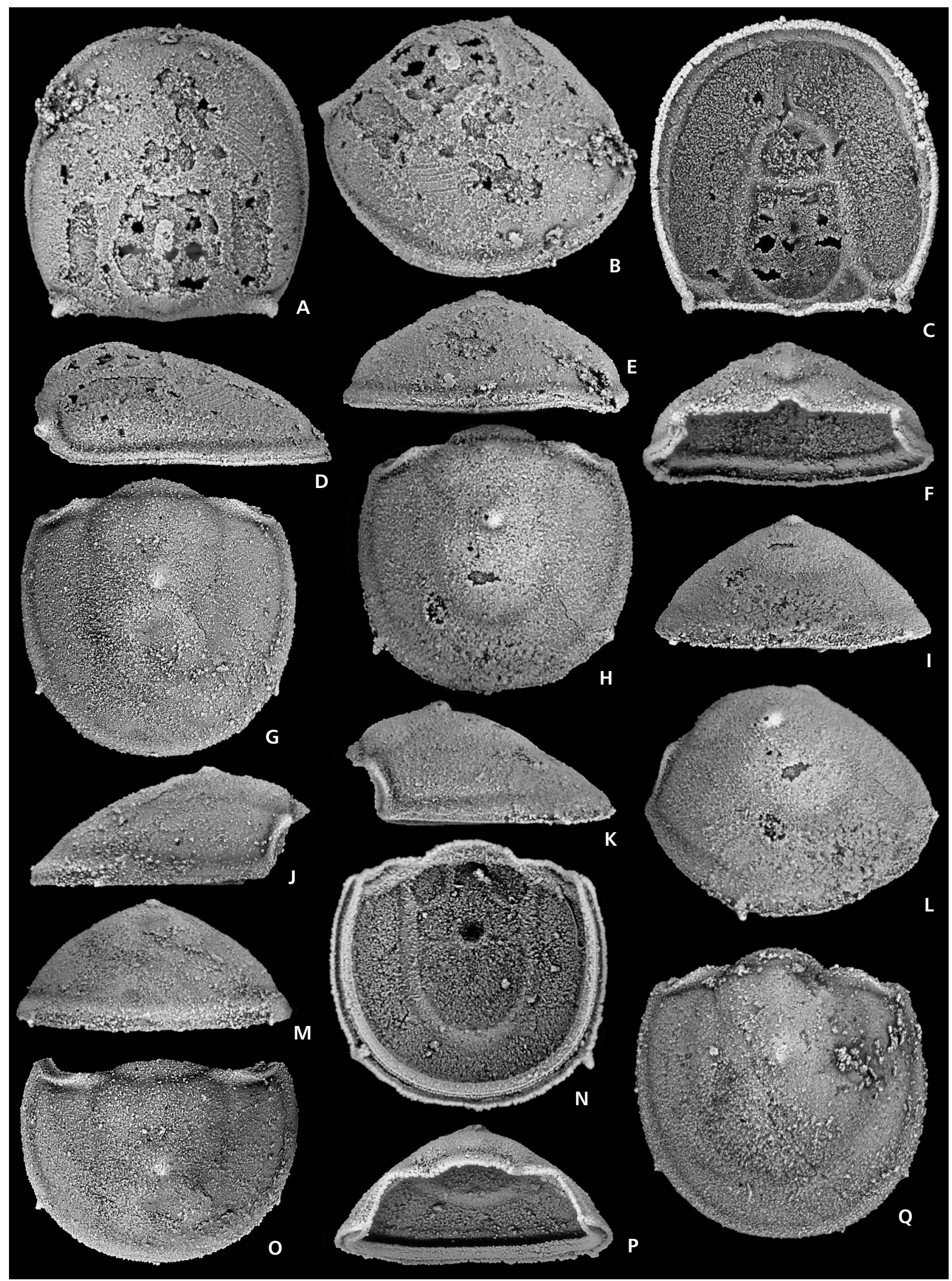




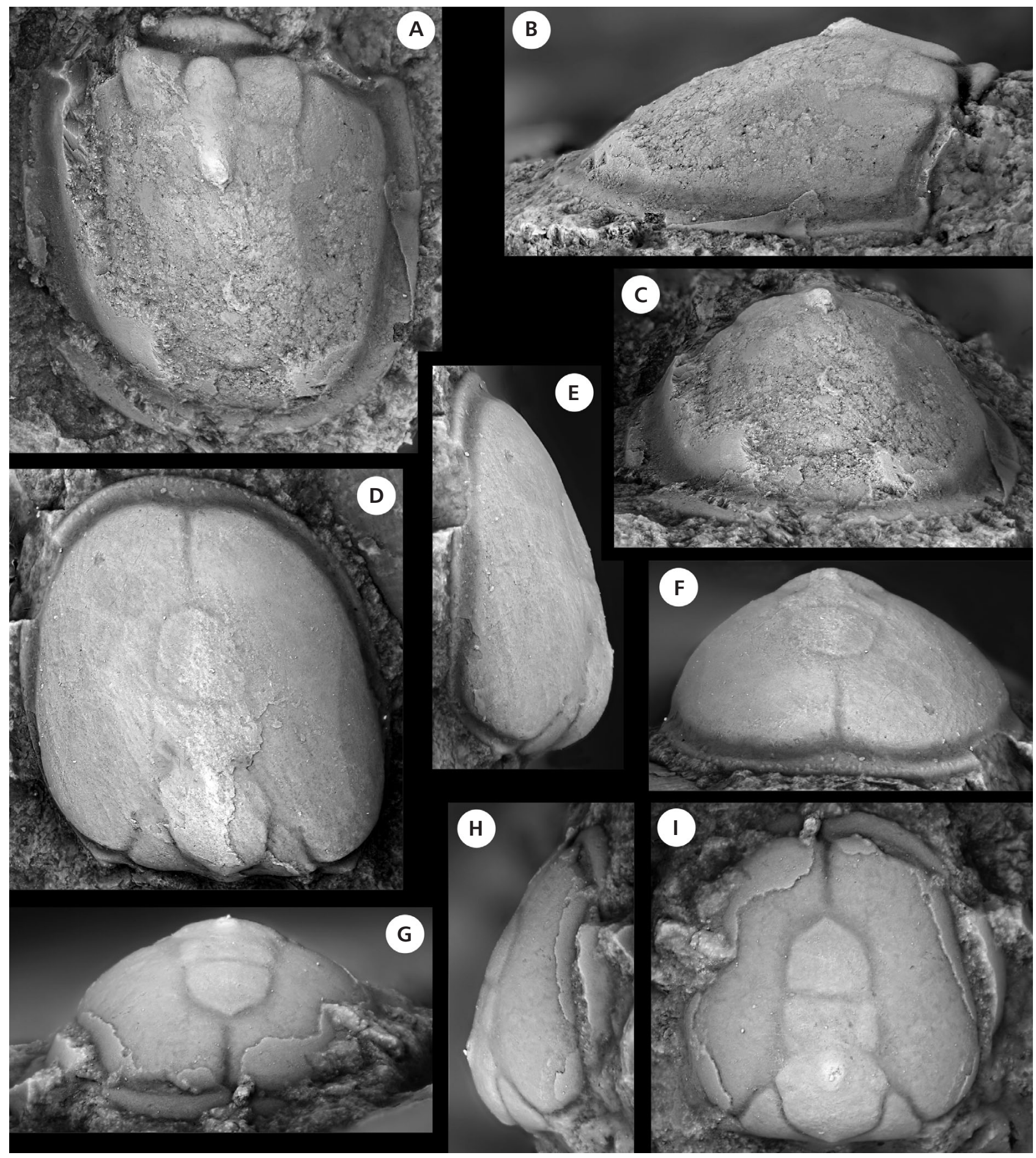

Figure 11. Lotagnostus sp. indet. from the Rabbitkettle Formation, section CC, Mountain River region, Mackenzie Mountains, northern Canada (Westrop 1995). - A-C - pygidium, dorsal, lateral and posterior views, ROM 49115, × 12. - D-F - cephalon, dorsal, lateral and anterior views, ROM 49114, × 12. • G-I - cephalon, anterior, lateral and dorsal views, ROM 49116, × 16 .

Figure 10. Lotagnostus cf. L. obscurus Palmer, 1955, from the Bullwhacker Member, Windfall Formation, ridge along north side of Barton Canyon, Cherry Creek Range, Nevada (Adrain \& Westrop 2004), collection CHC-1-137.9. • A-F - cephalon, dorsal, anterior-oblique, ventral, lateral, anterior and posterior views, SUI 126436, × 25. • G, J, M, O - pygidium, dorsal, lateral, posterior and anterior-tilted views, SUI 126437, × 20. • H, I, K, L, N, P-pygidium, dorsal, posterior, lateral, posterior oblique, ventral and anterior views, SUI $126438, \times 25 \cdot \bullet \mathrm{Q}-$ pygidium, dorsal view, SUI $126439, \times 20$. 
to Palmer's types. Even allowing for their much smaller sizes, the strongly convex glabella of the cephalon and equally prominent axes of the pygidia rule out any relationship with the Laurentian material. They may represent a species of Micragnostus.

\section{Lotagnostus cf. L. obscurus Palmer, 1955 Figure 10}

cf. 1955 Lotagnostus obscurus Palmer; Palmer, p. 19, figs 5-7, 10.

non 2008 Lotagnostus obscurus Palmer. - Ergaliev \& Ergaliev, p. 46 , pl. 42 , figs $6-8$.

Occurrence. - Bullwhacker Member, Windfall Formation, ridge along north side of Barton Canyon, collection CHC-1-137.9 (Adrain \& Westrop 2004).

Discussion. - Silicified sclerites of an effaced species of Lotagnostus from the Windfall Formation at Barton Canyon, Nevada, are important because they provide stratigraphic context that is missing from the occurrence of $L$. obscurus Palmer some $115 \mathrm{~km}$ to the southwest, in the Eureka District. They are part of an assemblage that includes the trilobites Hungaia Walcott, 1914 and Naustia Ludvigsen, 1982, and were collected from a horizon that is $133.1 \mathrm{~m}$ below a trilobite fauna described by Adrain \& Westrop (2004) that correlates into the upper Illaenurus Zone of Alberta (Westrop 1986) and the Prosaukia pyrene Subzone of Texas (Longacre 1970). Lotagnostus cf. L. obscurus may therefore be the oldest representative of the genus in Laurentia, occurring in strata that likely correlate into the lower Illaenurus zone or perhaps into the upper Ellipsocephaloides Zone of the type Sunwaptan (see also Palmer 1955, p. 87, who suggested that type L. obscurus may be "Franconia" in age).

All of the silicified sclerites are much smaller than Palmer's types, so we cannot be sure whether they are conspecific with L. obscurus. They show that the glabella and pygidial axis are differentially expressed between the dorsal and ventral surfaces of the exoskeleton, with segmentation defined only ventrally. This parallels the differences between testate and exfoliated sclerites of $L$. $o b$ scurus (Fig. 7A-C, G-I), and in other externally effaced species (e.g., Fig. 8I-L). Compared to L. obscurus, the pygidial axis of L. cf. L. obscurus (Fig. 10N) is a little shorter, but the pattern of segmentation is comparable, including the F1 furrows that are not connected medially. This latter feature separates L. cf. L. obscurus from L. ergodes (Fig. 8J-L) and L. irretitus (Fig. 9H-I). The glabella of L. cf. L. obscurus (Fig. 10C) seems to be relatively shorter than in the exfoliated paratype of $L$. $o b$ scurus, and both the transglabellar F3 furrow and the axial furrows appear to be better defined.

\section{Lotagnostus sp. indet.}

Figure 11

1995 Lotagnostus americanus (Billings, 1860). - Westrop, p. 15 , pl. 1, figs $17-20$.

Occurrence. - Rabbitkettle Formation, Mountain River area, Mackenzie Mountains, northern Canada (collection CC 330 of Westrop 1995; Naustia papilio Fauna).

Discussion. - Three sclerites from the Mackenzie Mountains are poorly preserved and relatively effaced. The smaller cephalon (Fig. 11G-I) is an internal mold that shows details of glabellar morphology. The basal lobes are short, and F2 is only weakly expressed on the ventral surface. The preglabellar median furrow is well-incised, and is also clearly defined on the larger cephalon (Fig. 11D-F). The expression of this furrow is one of the more obvious contrasts between the Canadian material and L. obscurus Palmer (e.g., Fig. 7A-C, G-I). As far as can be determined, proportions and segmentation of the axis of the associated pygidium (Fig. 11A-C) are similar to those of L. obscurus (Fig. 7D-F). It is possible that L. obscurus and $L$. sp. indet. will prove to represent a single species, but this cannot be demonstrated with the available samples.

\section{Acknowledgements}

Adrain and Westrop gratefully acknowledge support from National Science Foundation grants EAR 9973065 and EAR 0308685, and Landing is equally grateful for support from the New York State Museum and previous NSF grants. Conrad Labandiera, Mark Florence and Daniel Levin at the National Museum of Natural History, Washington, Jean Dougherty and Michele Coyne at the Geological Survey of Canada, Ottawa, John Laurie, Geoscience Australia, Canberra, and Randy Miller at the New Brunswick Museum, Saint John, facilitated loans of type and other material. Roger Burkhalter assisted in the lab at the University of Oklahoma; at the University of Iowa, Neo McAdams photographed sclerites of Lotagnostus cf. L. obscurus. Discussion with Adrian Rushton sharpened SRW's perception of the differences between Lotagnostus trisectus from England and Wales and L. americanus. We thank Franco Tortello and an anonymous reviewer for helpful comments on the manuscript.

\section{References}

AdRAin, J.M. \& WeStroP, S.R. 2004. A Late Cambrian (Sunwaptan) silicified trilobite fauna from Nevada. Bulletins of American Paleontology 365, 1-56.

AHLBERG, P. \& AHLGREN, J. 1996. Agnostids from the Upper Cambrian of Vastergötland, Sweden. GFF 118, 129-140. DOI 10.1080/11035899609546247 
Allen, P.M., JACKSON, A.A. \& Rushton, A.W.A. 1981. The stratigraphy of the Mawddach Group in the Cambrian succession of North Wales. Proceedings of the Yorkshire Geological Society 43, 295-329. DOI 10.1144/pygs.43.3.295

Angelin, N.P. 1851. Palaeontologica Suecica, Pars I: Iconographia Crustaceorum Formationis Transitionis. 24 pp. Weigel, Lund.

APOllonov, M.K., ChugaEVA, M.N. \& DuBinina, S.V. 1984. Trilobites and conodonts from the Batyrbay section (uppermost Cambrian-Lower Ordovician) in Maly Karatau Range (atlas of the palaeontological plates). 48 pp. Nauka, Alma-Ata. [in Russian]

Apollonov, M.K., ChugaeVA, M.N., Dubinina, S.V \& ZHEMCHUZHNIKOV, V.G. 1988. Batyrbay section, south Kazakhstan, U.S.S.R. - Potential stratotype for the Cambrian-Ordovician boundary. Geological Magazine 25, 445-449. DOI 10.1017/S0016756800013066

BABCOCK, L.E. \& PENG, S.-C. 2007. Cambrian chronostratigraphy: Current state and future plans. Palaeogeography, Palaeoclimatology, Palaeoecology 254, 62-66. DOI 10.1016/j.palaeo.2007.03.011

BAO, J.S. \& JAGO, J.B. 2000. Late Late Cambrian trilobites from near Birch Inlet, southwestern Tasmania. Palaeontology 43, 881-917. DOI 10.1111/1475-4983.00154

BILLINGS, E. 1860. On some new species of fossils from the limestone at Point Levis opposite Quebec. Canadian Naturalist 5, 301-324.

BILLINGS, E. 1865. Palaeozoic Fossils, Volume 1, 169-344. Geological Survey of Canada, Montreal.

BRogniarT, A. 1822. Les trilobites, 1-65. In BROGNIART, A. \& DESMART, A.-G. Histoire naturelle de crustacés fossiles, sous les raportes zoölogiques et géologiques. F.-G. Lavrault, Paris.

ClARK, T.H. 1924. The paleontology of the Beekmantown Series at Lévis, Quebec. Bulletins of American Paleontology 10, $1-134$.

ERGALIEV, G.K. 1983. Some trilobites from the Upper Cambrian and Lower Ordovician of the Greater Karatau and Ulutau, 35-66. In APOLLONOV, M.K., BANDELETOV, S.M. \& IVSHIN, N.K. (eds) The Lower Paleozoic Stratigraphy and Paleontology of Kazakhstan. Akademiya "Nauk" Kazakhskoi SSR, AlmaAta. [in Russian]

ERGaliEv, G.K. \& ERGaliev, F. 2008. Middle and Upper Cambrian Agnostida of the Askai National Geological Reserve, south Kazakhstan (Kyrshabakty River, Malyi Karatau Range). 376 pp. Gylum, Almaty. [in Russian]

GEYER, G. \& SHERGOLD, J. 2000. The quest for internationally recognized divisions of Cambrian time. Episodes 23, 188-195.

HARRINGTON, H.J. \& LEANZA, A.F. 1957. Ordovician trilobites of Argentina. Department of Geology, University of Kansas, Special Publication 1, 1-276.

HeNNINGSMOEN, G. 1957. The trilobite Family Olenidae with description of Norwegian material and remarks on the olenid and Tremadocian series. Skrifter utgitt ave Det Norske Videnskaps-Academi i Oslo. 1. Matematisk-naturvidenskapeilig klasse 1, 1-303.

Howell, B.F. 1935. Cambrian and Ordovician trilobites from Hérault, southern France. Journal of Paleontology 9, 222-238.

HuTCHINSON, R.D. 1952. The stratigraphy and trilobite faunas of the Cambrian sedimentary rocks of Cape Breton Island. Geological Survey of Canada Memoir 263, 1-124.

LAKE, P. 1906. A monograph on the British Cambrian trilobites. Palaeontographical Society Monograph, Part 1, 1-28.

LANDING, E. 1996. Avalon - Insular continent by the latest Precambrian, 27-64. In NANCE, R.D. \& THOMPSON, M. (eds)
Avalonian and related peri-Gondwanan terranes of the circum-North Atlantic. Geological Society of America, Special Paper 304.

LANDING, E., WESTROP, S.R. \& ADRAIN, J.M. 2011. The Lawsonian Stage - the Eoconodontus notchpeakensis (Miller, 1969) FAD and HERB carbon isotope excursion define a globally correlatable terminal Cambrian stage. Bulletin of Geosciences 86(3), 621-640.

LANDing, E., WeStrop, S.R., KRÖGER, B. \& ENGLish, A. 2011. Left behind - delayed extinction and a relict trilobite fauna in the Cambrian-Ordovician boundary succession (northeast Laurentia, New York). Geological Magazine 148, 529-557. DOI 10.1017/S0016756810000919

LaZarenko, N.P., Gogin, I.Y., Pegel, T.V., Sukhov, S.S., Abaimova, G.P., Egorova, L.I., Fedorov, A.B., RaEVSKAYA, E.G. \& USHATINSKAYA, G.T. 2008. Excursion 1 b. Cambrian stratigraphy of the northeastern Siberian Platform and potential stratotypes of lower boundaries of proposed Upper Cambrian Chekurovkian and Nelegerian stages in the Ogon'or Formation section at Khos-Nelege River: the boundaries are defined by the FAD of Agnostotes orientalis and Lotagnostus americanus, 61-139. In ROZANOV, A.Y. \& VARLAMOV, A.I. (eds) The Cambrian System of the Siberian Platform. Part 2: North-east of the Siberian Platform. PIN RAS, Moscow \& Novosibirsk.

LINNARSSON, J.G.O. 1880. Om förstenningarne i de svenska lagren med Peltura och Spaherophthalamus. Geologiska Föreningens $i$ Stockholm Förhandlingar 5, 132-161.

LONGACRE, S.A. 1970. Trilobites of the Upper Cambrian Ptychaspid Biomere, Wilberns Formation, central Texas. Paleontological Society Memoir 4, 1-70.

LU, Y-H. 1954. Upper Cambrian trilobites from Santa, southeastern Kueichou. Acta Palaeontologica Sinica 2, 109-152. [in Chinese with English summary]

LU, Y-H. 1964. Trilobites, 31-41. In WANG, Y. (ed.) Index Fossils of South China. Science Press, Beijing. [in Chinese]

LU, Y-H. \& LIN, H-L. 1980. Cambrian-Ordovician boundary in western Zhejiang and the trilobites contained therein. Acta Palaeontologica Sinica 19, 118-135. [in Chinese]

LU, Y-H. \& LIN, H-L. 1984. Late Cambrian and earliest Ordovician trilobites of Jiangshan-Changshan area, Zhejiang, 45-143. In NANJING InstituTE OF GEOLOGY AND PALAEONTOLOGY (ed.) Stratigraphy and Palaeontology of Systemic Boundaries in China, Cambrian-Ordovician Boundary, volume 1. Anhui Science and Technology Publishing House, Hefei.

LU, Y-H. \& LIN, H-L. 1989. The Cambrian trilobites of western Zhejiang. Palaeontologica Sinica, Whole Number 178, New Series B, 25, 1-278. [in Chinese with English summary]

LUDVIGSEN, R. 1982. Upper Cambrian and Lower Ordovician trilobite biostratigraphy of the Rabbitkettle Formation, western District of Mackenzie. Royal Ontario Museum Life Sciences Contributions 134, 1-188.

Ludvigsen, R., Westrop, S.R. \& Kindle, C.H. 1989. Sunwaptan (Upper Cambrian) trilobites of the Cow Head Group, western Newfoundland, Canada. Palaeontographica Canadiana 6, 1-175.

M'Coy, F. 1849. On the classification of some British fossil Crustacea with notices of some new forms in the University collection at Cambridge. Annals and Magazine of Natural History (Series 2) 4, 161-179, 330-335, 392-414.

MATTHEw, G.F. 1901. New species of Cambrian fossils from Cape Breton. Bulletin of the Natural History Society of New Brunswick 4, 269-286. 
MATTHEW, G.F. 1903. Report on the Cambrian rocks of Cape Breton. Geological Survey of Canada Report 797, 1-246.

Miller, J.F., Ethington, R.L., Evans, K.R., Holmer, L.E., LOCH, J.D., POPOV, L.E., REPETSKI, J.E., RIPPERDAN, R.L. \& TAYLOR, J.F. 2006. Proposed stratotype for the base of the highest Cambrian stage at the first appearance datum of Cordylodus andresi, Lawson Cove section, Utah, USA. Palaeoworld 15, 384-405. DOI 10.1016/j.palwor.2006.10.017

NiELSEN, A.T. 1997. A review of Ordovician agnostid genera (Trilobita). Transactions of the Royal Society of Edinburgh: Earth Sciences 87, 463-501.

PALMER, A.R. 1955. Upper Cambrian Agnostidae of the Eureka District, Nevada. Journal of Paleontology 29, 86-101.

PALMER, A.R. 1962. Glyptagnostus and associated trilobites in the United States. Geological Survey Professional Paper 374-F, 1-49.

PEgEL, T.V. 2000. Evolution of trilobite biofacies in Cambrian basins on the Siberian platform. Journal of Paleontology 74, 1000-1019.

DOI 10.1666/0022-3360(2000)074<1000:EOTBIC>2.0.CO;2

PENG, S.-C. 1984. Cambrian-Ordovician boundary in the Cili-Taoyuan border area, northwestern Hunan, 285-405. In NANJING INSTITUTE OF GEOLOGY AND PALAEONTOLOGY, ACADEMIA SINICA (ed.) Stratigraphy and paleontology of systemic boundaries in China, Cambrian and Ordovician boundary 1. Anhui Science and Technology Publishing House, Hefei.

PENG, S.-C. 1992. Upper Cambrian biostratigraphy and trilobite faunas of the Cili-Taoyuan area, northwestern Hunan. Memoirs of the Association of Australasian Palaeontologists 13, 1-119.

PENG, S.-C. \& BABCOCK, L.E. 2005. Two Cambrian agnostoid trilobites, Agnostotes orientalis (Kobayashi, 1935) and Lotagnostus americanus (Billings, 1860): Key species for defining global stages of the Cambrian System. Geosciences Journal 9, 107-115. DOI 10.1007/BF02910573

PenG, S.-C. \& Robison, R.A. 2000. Agnostoid biostratigraphy across the Middle-Upper Cambrian boundary in Hunan, China. Paleontological Society Memoir 53, 1-104.

PRATT, B.R. 1992. Trilobites of the Marjuman and Steptoean stages (Upper Cambrian), Rabbitkettle Formation, southern Mackenzie Mountains, northwest Canada. Palaeontographica Canadiana 9, 1-179.

RASETTI, F. 1944. Upper Cambrian trilobites from the Lévis conglomerate. Journal of Paleontology 18, 229-258.

RASETTI, F. 1945. New Upper Cambrian trilobites from the Lévis Conglomerate. Journal of Paleontology 19, 462-478.

RASETTI, F. 1959. Trempealeauan trilobites from the Conococheague, Frederick, and Grove limestones of the central Appalachians. Journal of Paleontology 33, 375-398.

REINHARDT, J. 1974. Stratigraphy, sedimentology and Cambrian-Ordovician paleogeography of the Frederick valley, Maryland. Maryland Geological Survey Report of Investigations $23,1-74$.

RoBISON, R.A. 1976. Middle Cambrian biostratigraphy of the Great Basin. Brigham Young University Geological Studies 23, 93-109.

RusCONI, C. 1951. Trilobitas cámbricos del Cerro Pelado (Mendoza). Boletín Paleontológico de Buenos Aires 24, 1-4.

RUSCONI, C. 1955. Más fósiles cámbricos y ordovícicos de San Isidro, Mendoza. Boletín Paleontológico de Buenos Aires 31, 1-4.

Rushton, A.W.A. 2009. Revision of the Furongian agnostoid Lotagnostus trisectus (Salter). Memoirs of the Association of Australasian Palaeontologists 37, 273-279.
SALTER, J.W. 1864. Figures and descriptions illustrative of British organic remains. Decade 11, Trilobites (chiefly Silurian). Memoirs of the Geological Survey of the United Kingdom, 1-64.

SHERGOLD, J.H. 1972. Late Upper Cambrian trilobites from the Gola Beds, western Queensland. Australian Bureau of Mineral Resources, Geology and Geophysics Bulletin 112, 1-127.

SHERGOLD, J.H. 1975. Late Cambrian and Early Ordovician trilobites from the Burke River Structural Belt, western Queensland, Australia. Australian Bureau of Mineral Resources, Geology and Geophysics Bulletin 153, 1-251.

SHERGOLD, J.H., BORDONARO, O. \& LIÑÁN, E. 1995. Late Cambrian agnostoid trilobites from Argentina. Palaeontology 38, 241-257.

SHERGOLD, J.H., LAURIE, J.R. \& SUN, X. 1990. Classification and review of the trilobite Order Agnostida Salter. 1864: an Australian perspective. Australian Bureau of Mineral Resources, Geology and Geophysics, Report 296, 1-93.

TAYLOR, M.E. 1976. Indigenous and redeposited trilobites from Late Cambrian basinal environments of central Nevada. Journal of Paleontology 50, 668-700.

Terfelt, F., ERIKSSON, M.E., AhlberG, P. \& BABCOCK, M.E. 2008. Furongian Series (Cambrian) biostratigraphy of Scandinavia - a revision. Norwegian Journal of Geology 88, 73-87.

TORTELLO, M.F. \& BORDONARO, O.L. 1997. Cambrian agnostoid trilobites from Mendoza, Argentina: a systematic revision and biostratigraphic implications. Journal of Paleontology 71, 74-86.

Troedsson, G.T. 1937. On the Cambro-Ordovician faunas of western Quruq Tagh, eastern Tien-Shan. Palaeontologia Sinica $2,1-74$.

WALCOTT, C.D. 1914. Dikelocephalus and other genera of the Dikelocephalinae. Smithsonian Miscellaenous Collections 57(13), 345-412.

WESTERGÅRD, A.H. 1922. Sveriges olenidskiffer. Sveriges Geologiska Undersokning, Series Ca 18, 1-205.

WESTERGÅRD, A.H. 1944. Borrningar genomi Skånes alunskiffer 1941-42. Sveriges Geologiska Undersokning, Series C 459, 1-45.

WESTERGÅRD, A.H. 1947. Supplementary notes on the Upper Cambrian trilobites of Sweden. Sveriges Geologiska Undersokning, Series C 479, 1-35.

WeStROP, S.R. 1986. Trilobites of the Upper Cambrian Sunwaptan Stage, southern Canadian Rocky Mountains, Alberta. Palaeontographica Canadiana 3, 1-175.

WESTROP, S.R. 1995. Sunwaptan and Ibexian (Upper Cambrian-Lower Ordovician) trilobites of the Rabbitkettle Formation, northern Mackenzie Mountains, northwest Canada. Palaeontographica Canadiana 12, 1-75.

Whittington, H.B., Chatterton, B.D.E., Speyer, S.E., FORTEY, R.A., OWENS, R.M. et al. 1997. Treatise on Invertebrate Paleontology, Part O, Arthropoda 1, Trilobita Revised. 530 pp. Geological Society of America \& University of Kansas, Boulder, Colorado \& Lawrence, Kansas.

WhiteHousE, F.W. 1936. The Cambrian faunas of northeastern Australia, Part 1, stratigraphic outline; Part 2, Trilobita (Miomera). Memoirs of the Queensland Museum 11, 59-112.

XIANG, L-W. \& ZHANG, T.R. 1985. Systematic descriptions of trilobite fossils, 64-136. In WANG, Z. (ed.) Stratigraphy and trilobite faunas of the Cambrian in the western part of northern Tianshan, Xinjiang. Peoples' Republics of China Ministry of Geology and Mineral Resources Geological Memoirs, Series 2, 4.

ZHOU, Z, LI, J. \& QU, X. 1982. Trilobita. Paleontological Atlas of northwest China, Shaanxi-Gansu-Ningxia, Volume 1,215-294. 